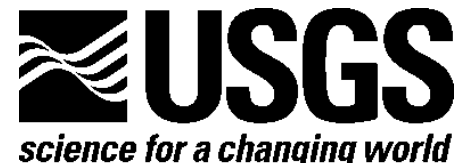

Prepared in collaboration with the South Florida Water Management District

\title{
Preliminary Use of Uric Acid as a Biomarker for Wading Birds on Everglades Tree Islands, Florida, United States
}

By Anne L. Bates, William H. Orem, Susan Newman, Dale E. Gawlik, Harry E. Lerch, Margo D. Corum, and Monica Van Winkle

Open-File Report 2009-1203

U.S. Department of the Interior U.S. Geological Survey 


\section{U.S. Department of the Interior \\ KEN SALAZAR, Secretary}

\section{U.S. Geological Survey \\ Marcia K. McNutt, Director}

U.S. Geological Survey, Reston, Virginia: 2010

For product and ordering information:

World Wide Web: http://www.usgs.gov/pubprod

Telephone: 1-888-ASK-USGS

For more information on the USGS-the Federal source for science about the Earth, its natural and living resources, natural hazards, and the environment:

World Wide Web: http://www.usgs.gov

Telephone: 1-888-ASK-USGS

Suggested citation:

Bates, A.L., Orem, W.H., Newman, Susan, Gawlik, D.E., Lerch, H.E., Corum, M.D., and Van Winkle, Monica, 2010, Preliminary use of uric acid as a biomarker for wading birds on Everglades tree islands, Florida, United States: U.S. Geological Survey Open-File Report 2009-1203, 26 p., available only online.

Any use of trade, product, or firm names is for descriptive purposes only and does not imply endorsement by the U.S. Government.

Although this report is in the public domain, permission must be secured from the individual copyright owners to reproduce any copyrighted material contained within this report. 


\section{Contents}

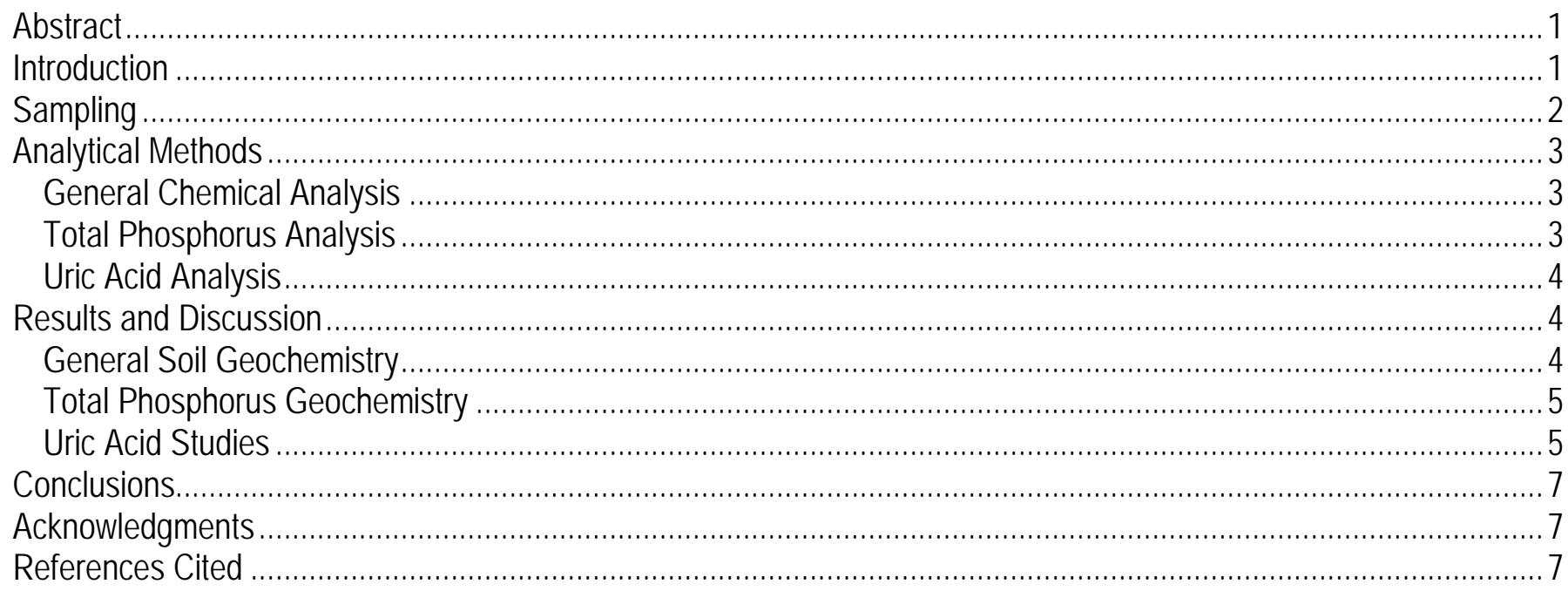

\section{Figures}

[Figures follow References Cited]

1. Map showing locations and names of tree islands in southern Florida as provided by Willard (2004)..... 10

2. Graphs of $(A)$ total carbon and $(B)$ total nitrogen contents (in percent dry weight) versus core depth (in centimeters) in core 1 collected at Rescue Strand on June 22, 2005.

3. Graphs of total carbon content (in percent dry weight) versus core depth (in centimeters) in soil cores from (A) the head of Tree Island 11 (TI-11), (B) the marsh of Tree Island 11, and (C) L67 Rookery Island....12

4. Graphs of total nitrogen content (in percent dry weight) versus core depth (in centimeters) in soil cores from (A) the head of Tree Island 11 (TI-11), (B) the marsh of Tree Island 11, and (C) L67 Rookery Island.... 13

5. Graphs of total sulfur content (in percent dry weight) versus core depth (in centimeters) in soil cores from (A) the head of Tree Island 11 (TI-11), (B) the marsh of Tree Island 11, and (C) L67 Rookery Island.

6. Graphs of total phosphorus content (in micrograms per gram dry weight) versus core depth (in centimeters) in soil cores from (A) Rescue Strand, $(B)$ the head of Tree Island 11 (TI-11), (C) the marsh of Tree Island 11, and (D) L67 Rookery Island.

7. Graphs of uric acid content (in micrograms per gram dry weight) versus total phosphorus content (in micrograms per gram dry weight) in soil cores from $(A)$ Rescue Strand, $(B)$ the head of Tree Island 11 (TI-11), and (C) the marsh of Tree Island 11.

8. Graphs of uric acid content (in micrograms per gram dry weight) versus total nitrogen content (in percent dry weight) in soil cores from (A) Rescue Strand, (B) the head of Tree Island 11 (TI-11), and $(C)$ the marsh of Tree Island 11. 


\section{Tables}

[Tables follow figures at the end of the report]

1. Sampling data for soil samples collected in the Everglades, Florida, at Rescue Strand (June 2005), 5 Mile Head (March 2006), Tree Island 11 (October 2007), and L67 Rookery Island (October 2007)

2. Total carbon $(\mathrm{C})$ and total nitrogen $(\mathrm{N})$ contents (in percent dry weight) for soil surface grab samples and core 1 segments collected at Rescue Strand on June 22, 2005.

3. Total carbon (TC), organic carbon (OC), total nitrogen (TN), and total sulfur (TS) contents in soil cores from the head and marsh of Tree Island 11 (TI-11) and from L67 Rookery Island.

4. Total phosphorus $(P)$ content (in micrograms per gram dry weight) for soil surface grab samples and core 1 segments collected at Rescue Strand on June 22, 2005

5. Total phosphorus content (in micrograms per gram dry weight) in soil cores from the head and marsh of Tree Island 11 (TI-11) and from L67 Rookery Island.

6. Uric acid content (in micrograms per gram dry weight) for soil surface grab samples, core 1 segments, and bird guano collected at Rescue Strand on June 22, 2005.

7. Uric acid content (in micrograms per gram dry weight) in bird droppings collected from nests (samples BB-1a through BB-11a and BB-12 through BB-15) and chicks (samples BB-1b through BB-11b).

8. Uric acid content (in micrograms per gram dry weight) in core segments and surface grab samples from Five Mile Head.

9. Uric acid content (in micrograms per gram dry weight) in soil cores from the head and marsh of Tree Island 11 (TI-11) and L67 Rookery Island. 


\section{Conversion Factors}

\begin{tabular}{|c|c|c|}
\hline Multiply & By & To obtain \\
\hline \multicolumn{3}{|c|}{ Length } \\
\hline mile (mi) & 1.609 & kilometer (km) \\
\hline nanometer (nm) & 0.00000003937 & inch (in.) \\
\hline micrometer $(\mu \mathrm{m})$ & 0.00003937 & inch (in.) \\
\hline millimeter (mm) & 0.03937 & inch (in.) \\
\hline centimeter (cm) & 0.3937 & inch (in.) \\
\hline \multicolumn{3}{|c|}{ Volume } \\
\hline milliliter (mL) & 0.0338 & ounce, fluid (fl. oz) \\
\hline liter (L) & 33.82 & ounce, fluid (fl. oz) \\
\hline liter (L) & 2.113 & pint (pt) \\
\hline liter (L) & 1.057 & quart (qt) \\
\hline liter (L) & 0.2642 & gallon (gal) \\
\hline liter (L) & 61.02 & cubic inch $\left(\right.$ in $\left.^{3}\right)$ \\
\hline \multicolumn{3}{|c|}{ Mass } \\
\hline microgram $(\mu g)$ & 0.00000003527 & ounce, avoirdupois (oz) \\
\hline milligram (mg) & 0.00003527 & ounce, avoirdupois (oz) \\
\hline gram (g) & 0.03527 & ounce, avoirdupois (oz) \\
\hline
\end{tabular}

Temperature in degrees Celsius $\left({ }^{\circ} \mathrm{C}\right)$ may be converted to degrees Fahrenheit $\left({ }^{\circ} \mathrm{F}\right)$ as follows: ${ }^{\circ} \mathrm{F}=\left(1.8 \mathrm{x}^{\circ} \mathrm{C}\right)+32$

Temperature in degrees Fahrenheit $\left({ }^{\circ} \mathrm{F}\right)$ may be converted to degrees Celsius $\left({ }^{\circ} \mathrm{C}\right)$ as follows:

${ }^{\circ} \mathrm{C}=\left({ }^{\circ} \mathrm{F}-32\right) / 1.8$ 



\title{
Preliminary Use of Uric Acid as a Biomarker for Wading Birds on Everglades Tree Islands, Florida, United States
}

\author{
By Anne L. Bates, ${ }^{1}$ William H. Orem, ${ }^{1}$ Susan Newman, ${ }^{2}$ Dale E. Gawlik, ${ }^{3}$ Harry E. Lerch, ${ }^{1}$ \\ Margo D. Corum, ${ }^{1}$ and Monica Van Winkle ${ }^{1}$
}

\begin{abstract}
Concentrations of organic biomarkers and concentrations of phosphorus in soil cores can potentially be used as proxies for historic population densities of wading birds on tree islands in the Florida Everglades. This report focuses on establishing a link between the organic biomarker uric acid found in wading bird guano and the high phosphorus concentrations in tree island soils in the Florida Everglades. Uric acid was determined in soil core sections, in surface samples, and in bird guano by using a method of high-performance liquid chromatography-mass spectrometry (HPLC-MS) developed for this purpose. Preliminary results show an overall correlation between uric acid and total phosphorus in three soil cores, with a general trend of decreasing concentrations of both uric acid and phosphorus with depth. However, we have also found no uric acid in a soil core having high concentrations of phosphorus. We believe that this result may be explained by different geochemical circumstances at that site.
\end{abstract}

\section{Introduction}

Tree islands are considered key indicators of the health of the Everglades ecosystem in Florida (United States) because of their sensitivity to both flooding and drought conditions. Tree islands also are important areas of biodiversity within the Everglades (Meshaka and others, 2002), providing rare upland habitat within a vast wetland. Tree islands support nesting colonies of wading birds (Gawlik and others, 2002). Soils on tree islands are a sink for nutrients (especially phosphorus) in the ecosystem and may play an important role in regulating nutrient dynamics (Orem and others, 2002). Although management strategies to restore and even create tree islands are being formulated, the published data on the age, developmental history, geochemistry, and response to hydrologic alterations of tree islands in the Everglades are limited (Sklar and van der Valk, 2002). The U.S. Geological Survey (USGS) and the South Florida Water Management District (SFWMD) are collaborating in an effort to understand the history of tree island development in the Everglades.

USGS studies of tree islands have focused on the integration of paleoecological (pollen, seed, charcoal analysis) and geochemical approaches to establish the history of tree island development and the ecological role of tree islands within the ecosystem. Dating by lead-210 $\left({ }^{210} \mathrm{~Pb}\right)$ and carbon-14 $\left({ }^{14} \mathrm{C}\right)$ methods and examination of soil cores collected on tree islands indicate that sites of tree island formation were drier than surrounding wetlands throughout Everglades history (last 4,000-5,000 years) and probably overlie topographic highs in the underlying limestone. Pollen studies of these cores suggest that tree island development, indicated by a transition from primarily marsh vegetation to ferns and trees, occurred 1,0003,000 years ago, depending on location in the Everglades (Willard and others, 2002).

\footnotetext{
${ }^{1}$ U.S. Geological Survey, 956 National Center, Reston, VA 20192, USA.

2 South Florida Water Management District, 3301 Gun Club Road, West Palm Beach, FL 33406, USA.

${ }^{3}$ Department of Biological Sciences, Florida Atlantic University, Boca Raton, FL 33431, USA.
} 
Contemporaneous with the development of the tree island vegetation was an increase in total phosphorus (TP) concentrations in tree island soils to levels greatly in excess of those observed in the surrounding marsh (200-400 micrograms per gram ( $\mu \mathrm{g} / \mathrm{g}$ ) dry weight; Orem and others, 2002). High soil TP concentrations (400 to more than 4,000 $\mu \mathrm{g} / \mathrm{g}$ dry weight; Ross and others, 2006) have been observed on most tree islands surveyed (17 total) in Water Conservation Area (WCA) 1, WCA 2, WCA 3, and Everglades National Park (Shark River Slough and Taylor Slough) (fig. 1). Soil TP concentrations decrease in the following order, island head $>$ near tail $>$ far tail $>$ marsh, suggesting that TP originating on or near the head of the island is gradually eroded, supplying nutrients for tail development (Orem and others, 2002). The high levels of soil TP on tree island heads are hypothesized to originate from bird guano (Orem and others, 2002). However, soil oxidation and hydrodynamic pumping of groundwater driven by evapotranspiration by trees may also play a role in concentrating TP (Wetzel and others, 2005; Ross and others, 2006). Phosphorus concentrations in soil pore water (1-440 micrograms per liter ( $\mu \mathrm{g} / \mathrm{L}))$ are low relative to the high levels of soil TP, suggesting that the TP deposited on tree islands is relatively unaffected by normal microbial recycling (Orem and others, 2002; Wetzel and others, 2005). Mineralogical analysis by x-ray diffraction shows the soil TP on tree island heads to be present primarily as an amorphous apatite. Thus, tree islands represent an overall sink for TP within the ecosystem.

Downcore profiles of TP in tree island soils (cores from tree island heads and tails) exhibit considerable variation over time, suggesting that the flux of phosphorus to individual tree islands may be variable in response to changes in bird populations (Orem and others, 2002) or for other reasons. Thus, profiles of soil TP in dated cores from tree islands may provide a proxy for following historical changes in the spatial distribution and abundance of wading bird populations in the ecosystem. In order to use this approach, however, it is necessary to establish a link between the soil TP on tree islands and bird guano. We have examined samples of bird guano for organic markers that could be linked to similar markers in soils from tree islands (unpub. data). The organic compounds were extracted from the guano and soils using microwave extraction with dichloromethane, and then compounds were identified by gas chromatography/mass spectrometry. Several sterols and fatty acids in the bird guano were identified, which preliminary studies of soils suggest may be useful biomarkers (Sklar and others, 2007).

Uric acid (UA) is a minor end product of nitrogen metabolism in the human body (the main product being urea) and is found in urine in small amounts. In some animals, especially birds, it is the main end product and is excreted in feces (Lonsdale and Sutor, 1971). It is likely that bird guano is the primary source of UA on tree islands, and perhaps it is the major source of phosphorus in soils on tree islands as well (Wetzel and others, 2005).

For the current study, we developed a high-performance liquid chromatography/mass spectrometry (HPLC-MS) method for determining UA in soils and bird guano. We examined the relationship between UA and TP in soil cores and investigated whether this relationship is stable over time. To this end, we collected soil core samples from tree islands with a current bird colony, from a drowned tree island not used as a colony site in recent times, and from marsh areas without trees.

\section{Sampling}

Bird guano and soil samples for an initial pilot study were collected from Rescue Strand tree island, located in the northeastern part of Water Conservation Area 3A (fig. 1). Rescue Strand was selected as the initial sampling location for studies of bird biomarkers because in most of the last 20 years, it has supported the largest colony of wading birds in the Everglades. Sampling was conducted on June 22, 2005, by scientists from the USGS (W. Orem and H. Lerch) and the SFWMD (S. Newman and E. Call). The sampling site was located on the eastern side of Rescue Strand, under a tree with recently abandoned nests. Coordinates of the site are in table 1 . Two types of soil samples were collected: (1) surface samples and (2) core samples.

On the basis of the preliminary results from the pilot study, additional samples were collected in other Everglades locations. Soil surface samples (1 and 2) and leaves coated with bird guano were collected from the head of 5 Mile Head in WCA 3A in March 2006. The thin soil layer overlying limestone 
bedrock made it impossible to collect a core at this site. Two cores (core 1 and core 2) were collected from the marsh east of 5 Mile Head, also in March 2006 (fig. 1, table 1). In October 2007, two soil cores were collected from Tree Island 11, a drowned tree island in WCA 2A; one core was from the head, and one was from a marsh. One core was collected from L67 Rookery Island in October 2007. The sampling site on L67 was under water. Sampling in October 2007 was conducted by scientists from the USGS (W. Orem and H. Lerch) and the SFWMD (S. Newman and M. Manna).

Cores were obtained by using Plexiglas hand-held piston corers having diameters of 10 and 2.5 centimeters $(\mathrm{cm})$. Details on the coring devices and coring procedure are presented elsewhere (Orem, Lerch, and Rawlik, 1997; Orem, Holmes, and others, 1999). This approach uses a monopod attached to the piston to keep it stationary at the soil surface, while handles attached around the Plexiglas core barrel are used to push the core barrel into the soil. Coring to the underlying limestone surface was accomplished. Differences in core depth between sites reflect the irregular limestone surface underlying the soil (table 1).

Core 1 from Rescue Strand was sliced into 2-cm intervals throughout its length. Other cores were sliced into 2-cm intervals down to $20 \mathrm{~cm}$. Below $20 \mathrm{~cm}$, the cores were sectioned into 5-cm segments. Samples identified as surface samples were collected by using a 2-cm-long aluminum coring tube section having an internal diameter of $10 \mathrm{~cm}$. The soil intervals were placed in clean I-Chem jars (cleaned for organic biomarker studies) and frozen on dry ice for shipment to USGS labs in Reston, Va. As noted in table 1, core segments collected at 5 Mile Head near the tail were lost during shipment to Reston. Core segments were kept frozen until ready for UA analysis except for the Rescue Strand samples, which were freeze-dried and ground for UA analysis. Aliquots of all soil samples were freeze-dried and ground for carbon, nitrogen, sulfur, and TP analyses. The freeze-dried and ground samples from Rescue Strand were divided for carbon, nitrogen, TP, and UA analyses.

Bird guano samples were collected by D. Gawlik and students at Florida Atlantic University from nests of wading birds (samples labeled BB-1a through BB-11a and BB-12 through BB-15) and directly from chicks (samples BB-1b through BB-11b). Bird species sampled were White Ibis (WHIB), Great Egret (GREG), Glossy Ibis (GLIB), and Tricolored Heron (TRHE).

\section{Analytical Methods}

\section{General Chemical Analysis}

Soil samples from both the surface samples and the cores were analyzed for total carbon (TC), organic carbon (OC), total nitrogen (TN), and total sulfur (TS). TC, OC, TN, and TS contents of soils were determined by using a Leco 932 CNS Analyzer (Leco Corporation, St. Joseph, Mich., USA). TC, TN, and TS were measured directly, after drying the ground, freeze-dried soil samples overnight at $60^{\circ} \mathrm{C}$. Organic carbon was determined after removal of inorganic carbon (IC), mostly carbonates, which constitutes a variable fraction of the TC content of soils from the Everglades.

To remove the IC, we used an acid vapor method, which was slightly modified from the methods of Hedges and Stern (1984) and Yamamuro and Kayanne (1995). Soil samples (5-6 milligrams (mg)) were weighed into prebaked $\left(450^{\circ} \mathrm{C}\right)$ silver cups, placed in an acid vapor chamber (a desiccator with beakers of concentrated $\mathrm{HCl}$ in the bottom), allowed to react for a minimum of 48 hours, dried at $60^{\circ} \mathrm{C}$, and analyzed. In addition to samples, blanks and calcium carbonate standards were also placed in the acid vapor chamber. Blanks consisted of prebaked $\left(450^{\circ} \mathrm{C}\right)$ empty silver cups and were used to monitor organic $\mathrm{C}$ contamination during the procedure. Calcium carbonate standards were used to visually determine when the acid vapor treatment was complete and to check on the efficiency of the acid vapor treatment.

All samples were analyzed in duplicate. Analytical precision (percentage relative standard deviation) was about 2 percent for TC, 4 percent for OC and TS, and 3 percent for TN.

\section{Total Phosphorus Analysis}

Total phosphorus was determined by using a slight modification of the method of Aspila and others (1976). This method involves baking approximately 0.5 gram (g) of dried soil at $550^{\circ} \mathrm{C}$ for 2 hours, 
extracting the residue in $1 \mathrm{M} \mathrm{HCl}$, and analyzing the extracted $\mathrm{P}$ using the standard phosphomolybdate method (Strickland and Parson, 1972) with a Brinkman PC900 fiber optic colorimeter. Analytical precision (percentage relative standard deviation or \%RSD) for total P based on replicate analysis is approximately \pm 5 percent.

\section{Uric Acid Analysis}

Uric acid (as urate anion) was determined in soil core sections, in surface samples, and in bird guano by using high-performance liquid chromatography-mass spectrometry (HPLC-MS). The analytical apparatus consisted of a Waters Corporation Alliance HT autosampler, a 996 photodiode array detector, and a ZQ MS mass detector. The chromatographic separation was performed with an Alltech Allsep anion exchange resin column (7 micrometers $(\mu \mathrm{m}), 100 \times 4.6$ millimeters $(\mathrm{mm})$ ), using as a mobile phase a bicarbonate buffer at neutral $\mathrm{pH}$ and methanol (90/10 volume per volume (v/v)) at a flow rate of 0.5 milliliter per minute (mL/min). Chromatograms recorded absorbance units at 285 nanometers (nm), the characteristic absorbance peak for urate anion. The total ion count (TIC) for all wavelengths between 210 $\mathrm{nm}$ and $320 \mathrm{~nm}$ was also recorded. The mass detector monitored negative ions at a mass-to-charge ratio $(\mathrm{m} / \mathrm{z})$ of 167.1 .

Uric acid standard stock solution was prepared at 100 micrograms per milliliter $(\mu \mathrm{g} / \mathrm{mL})$ by dissolving $0.0100 \mathrm{~g}$ of uric acid in bicarbonate buffer at a $\mathrm{pH}$ of 10.0 (uric acid was found to be insoluble in both methanol and neutral $\mathrm{pH}$ water) in a $100-\mathrm{mL}$ volumetric flask. Standards at lower concentrations were prepared by serial dilution. The detection limit at our instrumental conditions was $0.05 \mu \mathrm{g} / \mathrm{mL}$ for pure uric acid standards. Calibration curves were produced from uric acid peaks extracted from chromatograms of the photodiode TIC (total absorbance between $210 \mathrm{~nm}$ and $320 \mathrm{~nm}$ ), the SIR (single ion recording) at $m / z=167.1$, and the absorbance at $285 \mathrm{~nm}$.

The SIR was found to be the most sensitive indicator of urate; however, it was not used for quantification because of saturation effects at higher standard concentrations and because the peak intensity is highly sensitive to variations in instrumental conditions. The TIC was also not used for quantification because of the effects of unknown co-eluting anions in the sample chromatograms. The absorbance at $285 \mathrm{~nm}$ was used for quantification because, although less sensitive than the TIC or SIR signals, it produced the most consistent results in standard runs and it was a more specific indicator of urate anion than the TIC.

It was determined that an optimum ratio of $1 \mathrm{~g}$ (dry weight) sample to $8 \mathrm{~mL}$ buffer provided efficient extraction while maintaining detectable levels of uric acid. Samples were weighed out in plastic culture tubes. An appropriate volume of buffer was added. The sample slurry was shaken, centrifuged, and then filtered before transferring the filtrate to glass vials for HPLC-MS analysis. A second extraction was performed to confirm that all uric acid was extracted. Second extractions rarely produced any more uric acid than could be accounted for by dilution of buffer remaining after the first extraction.

For a small number of soil samples $(n=5)$, UA was extracted from both the wet (directly after thawing) and freeze-dried sample. A small amount of the wet soil was subsampled and dried in order to calculate the percentage of water in the wet sample. A comparison of results (after correcting for water content) obtained from wet and freeze-dried extractions showed that differences were no greater than the differences between duplicate runs by either method. There was no bias toward higher or lower concentrations by either method. Bird guano samples were not freeze-dried, but were all extracted wet. Results for bird guano are reported as percent of uric acid per dry weight, after correcting for water content.

\section{Results and Discussion}

\section{General Soil Geochemistry}

An observation made during sample handling was that the soil from L67 Rookery Island was different in texture from the soils collected at other sites. Generally, soil from other sites was spongy and 
absorbent of water, whereas the soil from L67 had a finer texture, did not hold much water, contained few recognizable plant parts, and was darker in color. The L67 site receives significant canal water in overflow from the L67 canal. Because the core site was under water, there may have been increased anaerobic microbial degradation of organic soils, including microbial reduction of sulfate in canal water. This degradation may explain the fine texture and darker color (metal sulfides) compared to other tree island soils.

At Rescue Strand, the surface grab samples generally had similar TC and TN concentrations (table 2). Average TC content in the surface grab samples was $44.06 \pm 2.09$ percent, and average TN was $3.34 \pm$ 0.30 percent. Both TC and TN show similar profiles (fig. 2) with depth, probably because the core penetrated an organic marl layer, which diluted the carbon and nitrogen contents as a percentage of the total dry weight.

Results for the head and marsh cores of Tree Island 11 and for the L67 Rookery Island core collected in October 2007 (table 3, fig. 3) show little difference in total carbon (percent dry weight, \% dry wt.) among the three cores. Total carbon contents in the L67 core did not show a clear trend with depth, whereas the TC contents in the cores from Tree Island 11 increased with depth. In organic soils, carbon tends to increase with depth due to preferential anaerobic microbial degradation of oxygen-containing organic moieties (for example, complex carbohydrates like cellulose (Orem and Hatcher, 1987)). This preferential loss of oxygen leads to an increase in carbon as a percentage of total weight, even though carbon is also being biodegraded. Organic carbon in all three cores is virtually equivalent to total carbon, within experimental error.

Total nitrogen (table 3, fig. 4) is somewhat higher in the L67 upper core segments (down to about 6 $\mathrm{cm}$ ) than in the same segments in the cores from Tree Island 11. However, overall, the TN data do not differ much between cores, suggesting that bird activity is not a major control on soil nitrogen.

Total sulfur (table 3, fig. 5) is generally a little higher in the near-surface segments of the marsh core from Tree Island 11 and in the L67 core than in the core from the head of Tree Island 11, possibly because of more oxic conditions or less historic sulfate input at the head of Tree Island 11.

\section{Total Phosphorus Geochemistry}

Total phosphorus contents in micrograms per gram dry weight are highest in the upper segments of core 1 collected at Rescue Strand in June 2005 and in all three cores collected in October 2007 (tables 4 and 5, fig. 6) and decrease with depth. A comparison of the three cores collected in October 2007 reveals that total phosphorus is at least twice as high in the L67 Rookery Island core segments as in either of the Tree Island 11 cores. Phosphorus contents are generally higher in the Tree Island 11 head core than in the Tree Island 11 marsh core. These differences are possibly due to the relative density of bird populations at these sites. Tree Island 11 is a drowned tree island, no longer housing a bird colony. It is interesting that these trends in phosphorus contents appear to persist even without a known current bird colony, though both wading birds and songbirds may still roost on the remaining vegetation, providing some guano input.

\section{Uric Acid Studies}

We set out to examine UA content in bird droppings and soils as part of the overall effort to examine biomarkers of wading birds on tree islands. Because UA is present in high concentrations in bird guano, its presence in soil is one potential indicator of the presence of wading birds. Changes in UA concentrations downcore could be potentially useful as indicators of historical bird populations. We were able to determine the presence of UA (as urate anion) in bird droppings and in soil using HPLC-MS methods in an initial pilot study using the samples collected at Rescue Strand. Results from Rescue Strand (table 6) indicate significant amounts of urate in bird guano (about 0.013 percent of wet weight), whereas no urate was detected in control marsh surface soil (Gumbo Limbo Marsh West) far from bird colonies. Surface soil samples from Rescue Strand contained measurable amounts of uric acid, and soil core segments from this site showed decreasing amounts of uric acid with depth (table 6). This pilot study showed the potential of this approach for examining changes in wading bird populations over time. 
Bird guano collected from bird nests by D. Gawlik and collaborators from Florida Atlantic University (table 7) provides end-member uric acid content in micrograms per gram dry weight. The uric acid content in pure bird guano is several orders of magnitude greater than the uric acid content in surface grab samples collected at the head of 5 Mile Head (table 8). Leaves with bird guano collected at this site have a UA content in the same range as pure bird guano collected from nests. Uric acid in surface soil samples collected from the head of 5 Mile Head have UA contents ranging from below the detection limit to $6.46 \mu \mathrm{g} / \mathrm{g}$ dry weight at this site (the range is indicative of sample heterogeneity). These results are comparable to the uric acid content in surface samples collected from Rescue Strand (0.5 to $7.9 \mu \mathrm{g} / \mathrm{g}$ dry weight). Clearly, UA becomes greatly diluted in soil and (or) it is unstable and decomposes over time. Uric acid contents in the near-surface segments of core 2 collected from 5 Mile Head marsh east (table 8) are about the same as those in the grab samples, while dropping off in the midcore sections. Concentrations of UA were below the detection limit in the near-bottom core segments. A shorter core having a smaller diameter (core 1) was collected nearby and shows very low UA contents in all core segments that were analyzed (near-surface, midcore, and near-bottom segments).

To determine the stability of uric acid in soil over time, we collected and analyzed additional cores: (1) a core from a drowned tree island (Tree Island 11, head), no longer inhabited by bird colonies, to determine if UA persists at bird island sites after major input ceases, (2) a control core from a nearby marsh site (Tree Island 11, marsh), away from the major center of bird population on the tree island, to determine background UA concentrations, and (3) a core from the site of a currently inhabited tree island (L67 Rookery Island) for characterization of UA concentrations in soils from a tree island with an active bird colony.

Both cores (head and marsh) taken from Tree Island 11 in October 2007 show a pattern of decreasing uric acid content with depth (table 9), similar to cores collected at 5 Mile Head and Rescue Strand. Total phosphorus is also higher in the near-surface segments of these cores and appears to be correlated with UA $\left(\mathrm{R}^{2}>0.64\right)$ in those core segments having quantifiable levels of UA (fig. 7). A correlation with total nitrogen (fig. 8) is not evident, probably because nitrogen is derived from plant material, and possibly fertilizer, as well as from UA. Nitrogen can also be lost to soil by plant uptake and by losses to the atmosphere during denitrification (Seitzinger, 1994). Uric acid content is generally higher in the core taken at the head of Tree Island 11 than in the core from the marsh of Tree Island 11; this difference probably indicates a higher bird population density at the head. The fact that UA is seen in the marsh core means that there is a considerable area of influence around the tree island, which may be caused either by lateral flow of soil or by the relatively large presence of birds near the tree islands.

A true control core should be taken from a marsh area much farther away from any center of bird activity. Because Tree Island 11 is a drowned tree island, the presence of UA in cores collected from the site shows that UA persists for some years in soil, although we do not know the original UA content in the soil. This question may be answered by examining the UA contents in core segments taken from L67 Rookery Island, which has a dense and active bird population. Surprisingly, this core showed virtually no uric acid (tables 5, 9), although the TP and TN contents were highest in that core. A number of possible explanations for this result may be offered based on this and other studies: (1) the soil in this core was anomalous compared to any observed before in these studies, as noted above, possibly due to local cycles of drought and flooding; (2) the type of soil influences the stability of UA; or (3) pore water redox (or $\mathrm{pH}$ ) conditions (the surface of the L67 core was under water) influence the availability of UA to degradation by anaerobically active bacteria (Karlsson and Barker, 1948). If the third explanation is the best explanation, then the usefulness of UA as an indicator of historical bird populations is called into question, or at least the careful selection of sampling sites must be ensured in order to obtain meaningful results. This approach would still be useful, however, for determining recent bird habitation on tree islands. The result that UA concentrations decrease with depth in all cores that have been analyzed to date suggests that UA decomposes in soil over time; however, we cannot state this conclusively because TP concentration also declines with depth. 


\section{Conclusions}

The objective of the study was to use downcore concentrations of organic markers and soil phosphorus concentrations as proxies for historic population densities of wading birds. We have identified uric acid (UA) as a potential marker, and this compound has been quantified in both bird guano and soils using an HPLC-MS analytical method developed for this purpose. A limited number of samples show an overall correlation between UA and total phosphorus.

Certain broad generalizations can be drawn from the results for UA. Surface soil samples tend to contain significantly more UA than any of the core sections. Soil from the core sections contains relatively higher UA concentrations in the uppermost sections compared to deeper sections of the core. Uric acid was not detected in a control sample from the surface section of a core collected in a marsh area (west of Gumbo Limbo tree island), far from areas having large bird populations. Bird guano contains several orders of magnitude greater concentration of UA than any of the soil samples. This result suggests that UA is greatly diluted in soil and (or) that UA degrades over time. The decrease in UA concentration with core depth suggests degradation over time. We had hoped to determine if there is degradation by comparing UA contents in a core from a tree island currently supporting a bird population (L67 Rookery Island) with a soil core from a drowned tree island (Tree Island 11), uninhabited by a bird colony for some years. However, the core from a tree island (L67) with a dense bird population contained high total phosphorus while showing virtually no UA content, possibly because of different sedimentologic or geochemical circumstances at that site. We intend to clarify the ambiguity introduced by this result by obtaining soil cores for UA analysis from a number of additional carefully selected sites.

\section{Acknowledgments}

We thank the South Florida Water Management District (Grant \#PC P501993) and the U.S. Geological Survey, Priority Ecosystems Studies Program (G. Ronnie Best, Coordinator) for financial support for this study. We thank Debra Willard (USGS) and Fred Sklar (SFWMD) for ideas related to tree island ecology and geochemistry. We also thank the students and colleagues of Dale Gawlik and Susan Newman for assistance in sample collection.

\section{References Cited}

Aspila, K.I., Agemian, H., and Chau, A.S.Y., 1976, A semi-automated method for the determination of inorganic, organic, and total phosphate in sediments: The Analyst, v. 101, p. 187-197.

Gawlik, D.E., Gronemeyer, Peg, and Powell, R.A., 2002, Habitat-use patterns of avian seed dispersers in the central Everglades, chap. 15 of Sklar, F.H., and van der Valk, Arnold, eds., Tree islands of the Everglades: Boston, Kluwer Academic Publishers, p. 445-468.

Hedges, J.L., and Stern, J.H., 1984, Carbon and nitrogen determinations of carbonate-containing solids: Limnology and Oceanography, v. 29, p. 657-663.

Karlsson, J., and Barker, H., 1948, Tracer experiments on the mechanism of uric acid decomposition and acetic acid synthesis by Clostridium acidiurici: Journal of Biological Chemistry, v. 178, no. 2, p. 891902.

Londsdale, K., and Sutor, D.J., 1971, Uric acid dehydrate in bird urine: Science, v. 172, p. 958.

Meshaka, W.E., Jr., Snow, Ray, Bass, O.L., Jr., and Robertson, W.B., Jr., 2002, Occurrence of wildlife on tree islands in the southern Everglades, chap. 13 of Sklar, F.H., and van der Valk, Arnold, eds., Tree islands of the Everglades: Boston, Kluwer Academic Publishers, p. 391-428. 
Orem, W.H., and Hatcher, P.G., 1987, Early diagenesis of organic matter in a sawgrass peat from the Everglades, Florida: International Journal of Coal Geology, v. 8, p. 33-54.

Orem, W.H., Holmes, C.W., Kendall, C., Lerch, H.E., Bates, A.L., Silva, S.R., Boylan, A., Corum, M., and Hedgman, C., 1999, Geochemistry of Florida Bay sediments; Nutrient history at five sites in eastern and central Florida Bay: Journal of Coastal Research, v. 15, p. 1055-1071.

Orem, W.H., Lerch, H.E., and Rawlik, Peter, 1997, Geochemistry of surface and pore water at USGS coring sites in wetlands of south Florida; 1994 and 1995: U.S. Geological Survey Open-File Report 97454, 70 p. (Also available at http://sofia.usgs.gov/publications/ofr/97-454/.)

Orem, W.H., Willard, D.A., Lerch, H.E., Bates, A.L., Boylan, Ann, and Corum, Margo, 2002, Nutrient geochemistry of sediments from two tree islands in Water Conservation 3B, the Everglades, Florida, chap. 5 of Sklar, F.H., and van der Valk, Arnold, eds., Tree islands of the Everglades: Boston, Kluwer Academic Publishers, p. 153-186.

Ross, M.S., Mitchell-Bruker, S., Sah, J.P., Stothoff, S., Ruiz, P.L., Reed, D.L., Jayachandran, K., and Coultas, C.L., 2006, Interaction of hydrology and nutrient limitation in the ridge and slough landscape of the southern Everglades: Hydrobiologia, v. 569, p. 37-59.

Seitzinger, S.P., 1994, Linkages between organic matter mineralization and denitrification in eight riparian wetlands: Biogeochemistry, v. 25, p. 19-39.

Sklar, Fred, Balci, Pinar, Cline, Eric, Cook, Mark, Cooper, Bill, Coronado, Carlos, Edelstein, Chris, Ferree, Michelle, Fitz, Carl, Furedi, M.A., Garrett, Brian, Gawlik, Dale, Gu, Ben, Hagerthey, Scot, Kobza, Mac, Miao, ShiLi, Newman, Sue, Orem, Bill, Palmer, Janise, Rutchey, Ken, Sindhoj, Erik, Thomas, Cassondra, Volin, John, and Wang, Naiming, 2007, Ecology of the Everglades Protection Area, chap. 6 of 2007 South Florida environmental report: West Palm Beach, Fla., South Florida Water Management District, p. 6-1 to 6-57. (Also available at https://my.sfwmd.gov/pls/portal/docs/PAGE/ PG_GRP_SFWMD_SFER/PORTLET_PREVREPORT/VOLUME1/chapters/v1_ch_6.pdf.)

Sklar, F.H., and van der Valk, Arnold, 2002, Tree islands of the Everglades; An overview, chap. 1 of Sklar, F.H., and van der Valk, Arnold, eds., Tree islands of the Everglades: Boston, Kluwer Academic Publishers, p. 1-18.

Strickland, J.D.H., and Parson, T.R., 1972, A practical handbook of seawater analysis: Ottawa, Canada, Fisheries Research Board of Canada, 310 p.

Wetzel, P.R., van der Valk, A.G., Newman, S., Gawlik, D.E., Troxler-Gann, T., Coronado-Molina, C.A., Childers, D.L., and Sklar, F.H., 2005, Maintaining tree islands in the Everglades; Nutrient redistribution is the key: Frontiers in Ecology and the Environment, v. 3, p. 370-376.

Willard, D.A., 2004, Tree islands of the Florida Everglades-Long-term stability and response to hydrologic change: U.S. Geological Survey Fact Sheet 2004-3095, 4 p. (Also available at http://pubs.usgs.gov/fs/2004/3095/.)

Willard, D.A., Holmes, C.W., Korvela, M.S., Mason, Daniel, Murray, J.B., Orem, W.H., and Towles, D.T., 2002, Paleoecological insights on fixed tree island development in the Florida Everglades, chap. 4 of Sklar, F.H., and van der Valk, Arnold, eds., Tree islands of the Everglades: Boston, Kluwer Academic Publishers, p. 117-151. 
Yamamuro, M., and Kayanne, H., 1995, Rapid direct determination of organic carbon and nitrogen in carbonate-bearing sediments with a Yanaco MT-5 CHN analyzer: Limnology and Oceanography, v. 40, p. 1001-1005. 


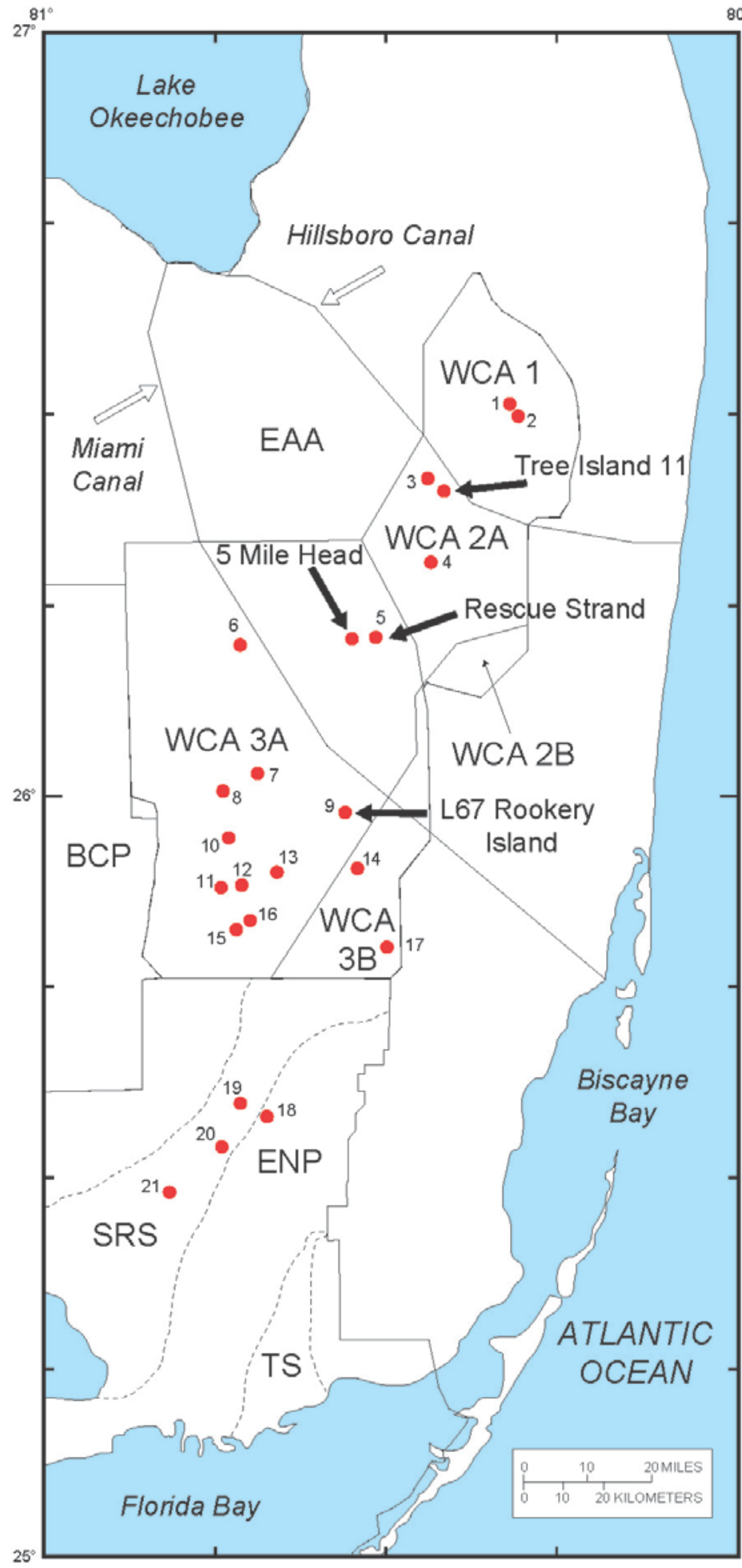

\section{Tree Island Key}

1 - Loxahatchee Pop-up Island

2 - Loxahatchee Strand Island

3 - T3 Island

4 - Treece's Island

5 - Rescue Strand

6 - 3AN1 Island

7 - Jessie Willie's Camp

8 - 3AS1 Island

9 - L67 Rookery/Colony Island

10 - 3AS2 Island

11 - 3AS3 Island

12 - Skinner's Camp

13 - 3AS5 Island

14 - Nuthouse Island

15 - 3AS4 Island

16 - Zaffke Island

17 - Gumbo Limbo Tree Island

18 - Black Hammock

19 - Gumbo Limbo Hammock

20 - Panther Mound

21 - Manatee Hammock

Figure 1. Map showing locations and names of tree islands in southern Florida as provided by Willard (2004). The four tree islands where samples were collected for this study are labeled on the map as Tree Island 11, 5 Mile Head, Rescue Strand, and L67 Rookery Island. Other features: BCP, Big Cypress Preserve; EAA, Everglades Agricultural Areas; ENP, Everglades National Park; SRS, Shark River Slough; TS, Taylor Slough; WCA, Water Conservation Area. Dashed lines indicate borders of sloughs. 
(A) Total Carbon vs. Core Depth at Rescue Strand

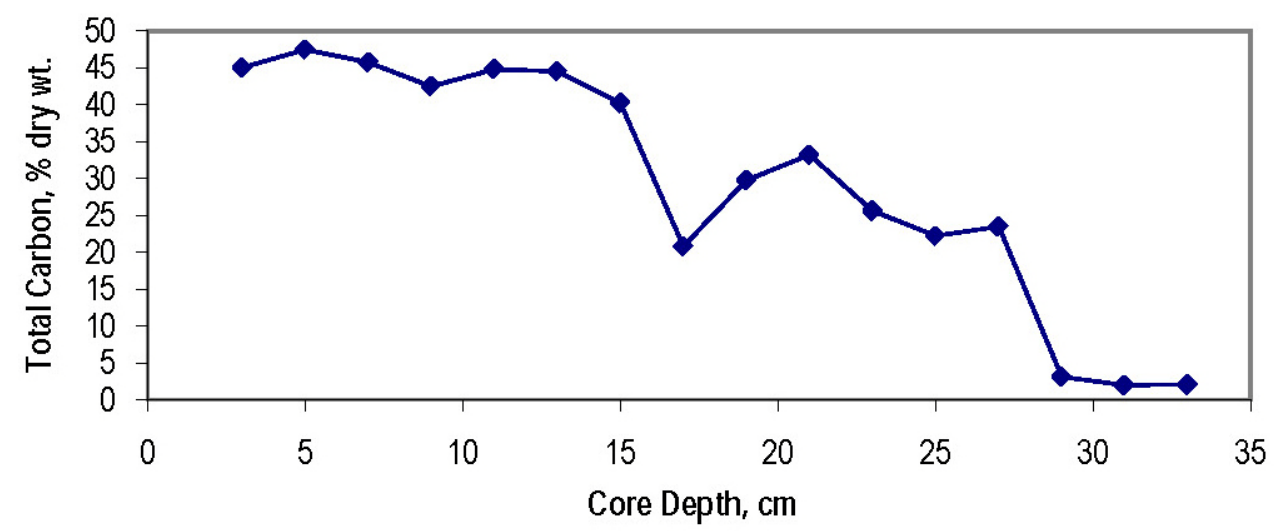

(B) Total Nitrogen vs. Core Depth at Rescue Strand

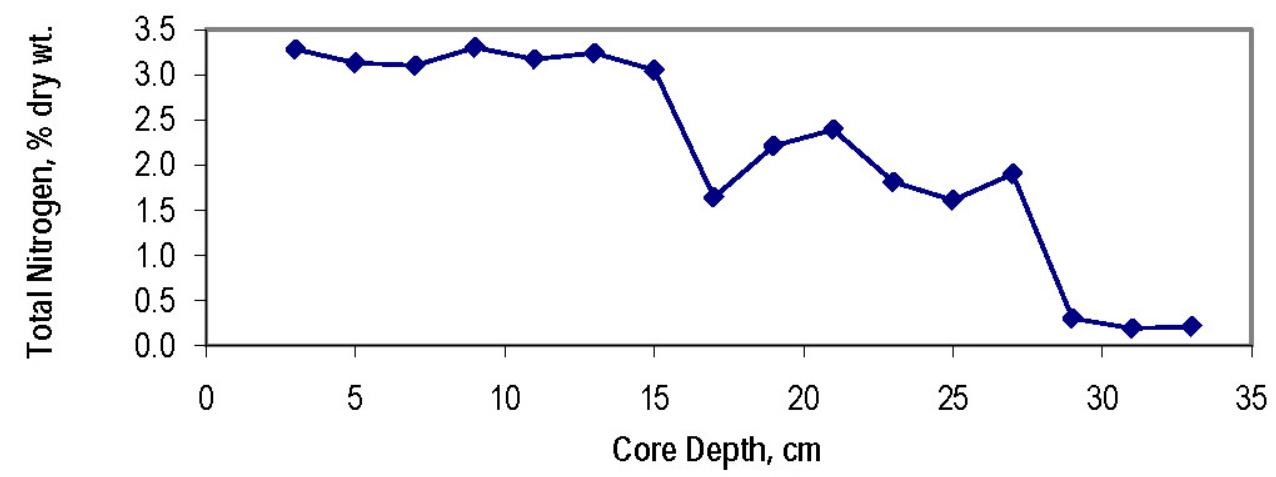

Figure 2. Graphs of $(A)$ total carbon and $(B)$ total nitrogen contents (in percent dry weight) versus core depth (in centimeters) in core 1 collected at Rescue Strand on June 22, 2005. All samples were analyzed in duplicate; data points plotted are averages of duplicate results shown in table 2 . 
(A) Total Carbon vs. Core Depth at TI-11 Head

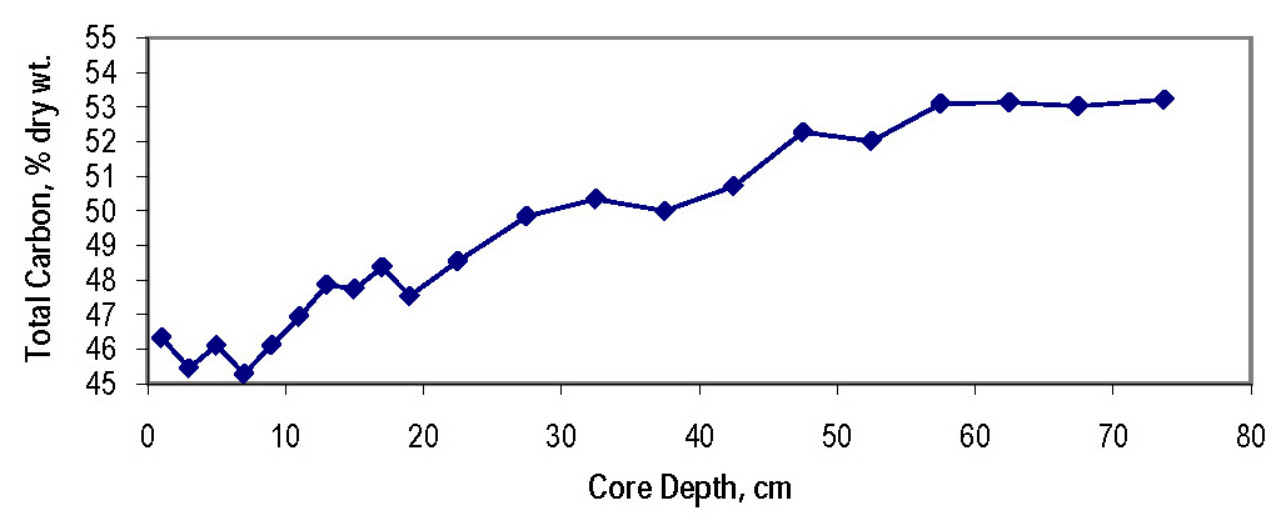

(B) Total Carbon vs. Core Depth at TI-11 Marsh

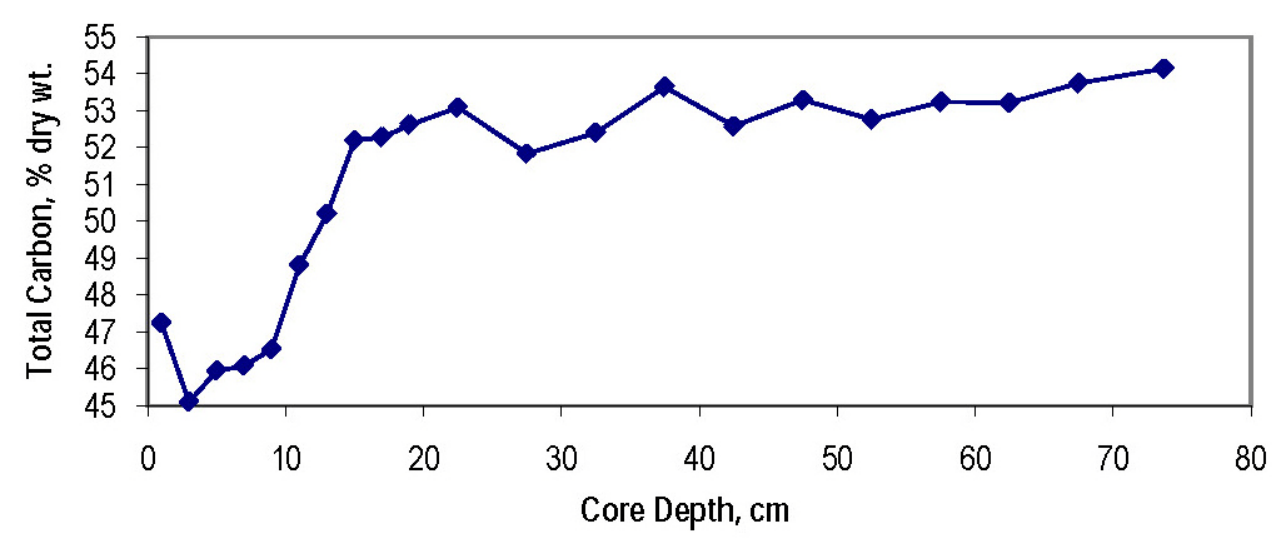

(C) Total Carbon vs. Core Depth at L67 Rookery Island

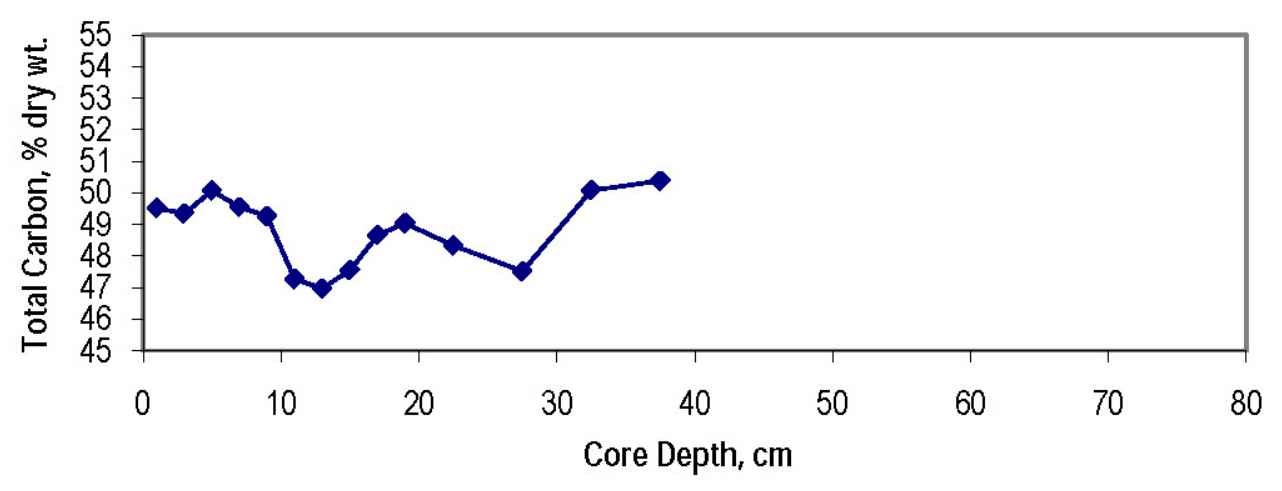

Figure 3. Graphs of total carbon content (in percent dry weight) versus core depth (in centimeters) in soil cores from (A) the head of Tree Island 11 (TI-11), (B) the marsh of Tree Island 11, and $(C)$ L67 Rookery Island. The cores were collected on October 12 and 13, 2007. All samples were analyzed in duplicate; data points plotted are averages of duplicate results shown in table 3 . 
(A) Total Nitrogen vs. Core Depth at TI-11 Head

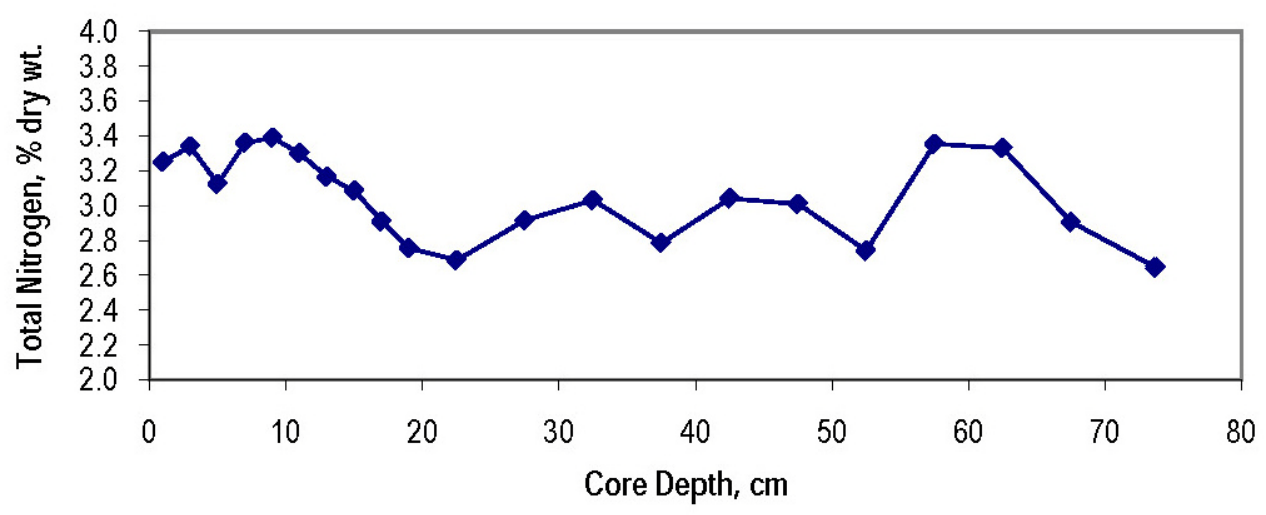

(B) Total Nitrogen vs. Core Depth at TI-11 Marsh

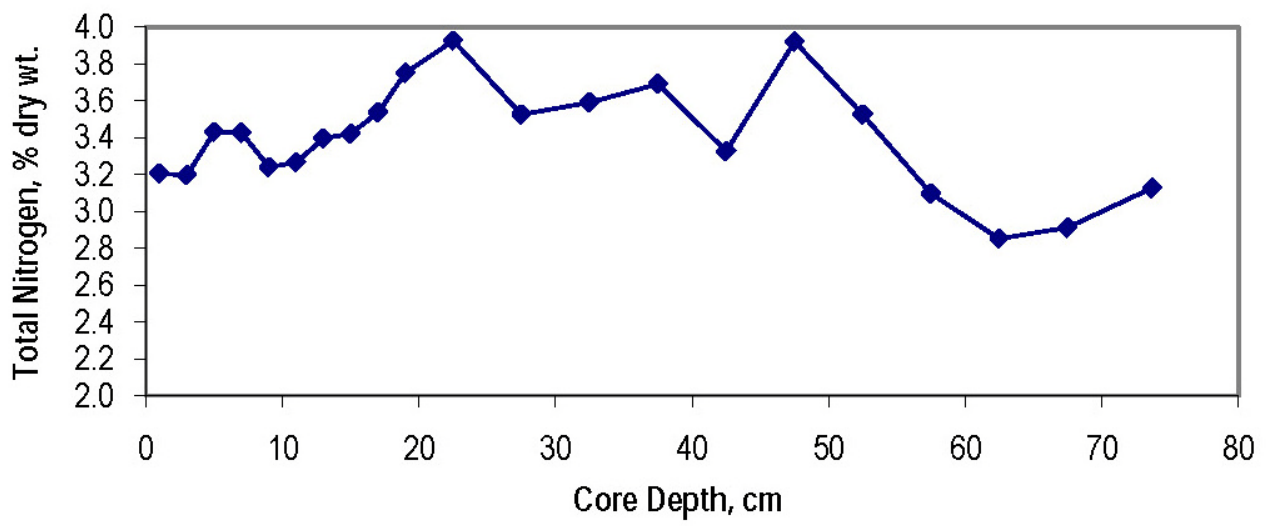

(C) Total Nitrogen vs. Core Depth at L67 Rookery Island

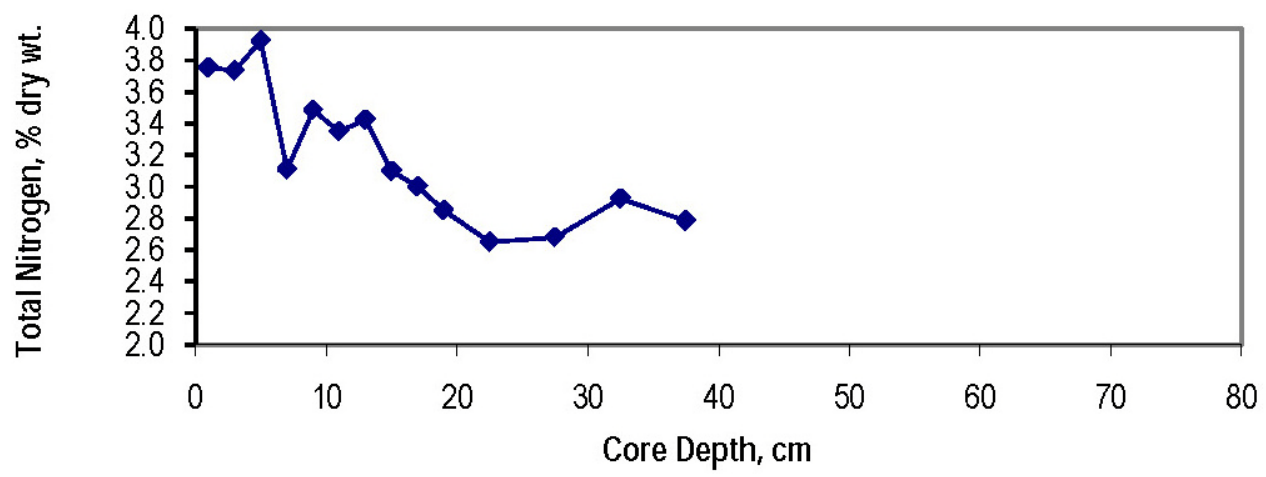

Figure 4. Graphs of total nitrogen content (in percent dry weight) versus core depth (in centimeters) in soil cores from (A) the head of Tree Island 11 (TI-11), (B) the marsh of Tree Island 11, and (C) L67 Rookery Island. All samples were analyzed in duplicate; data points plotted are averages of results shown in table 3. 
(A) Total Sulfur vs. Core Depth at TI-11 Head

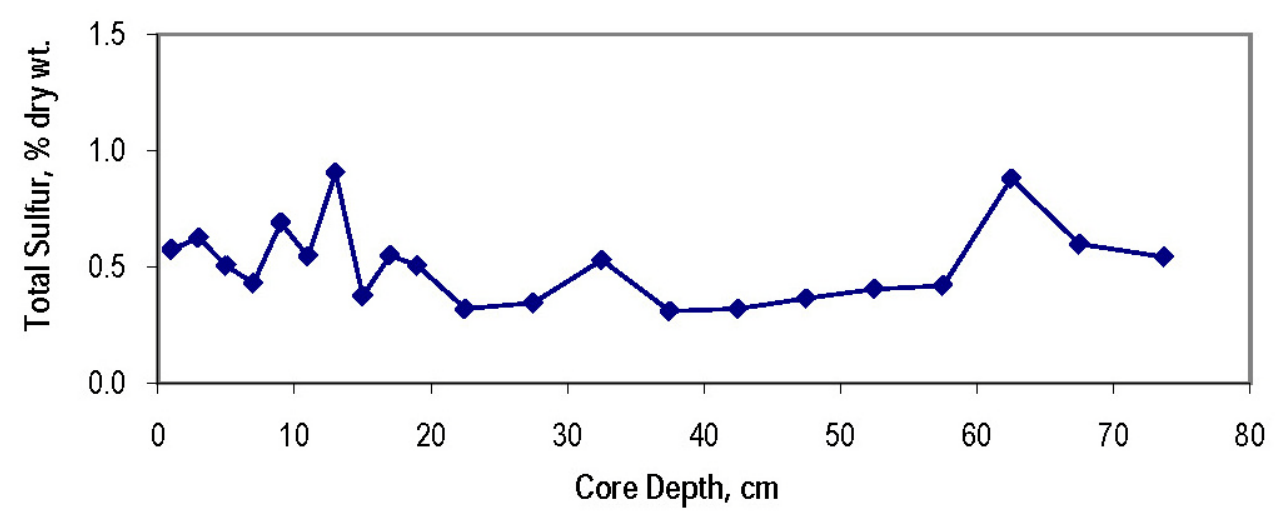

(B) Total Sulfur vs. Core Depth at TI-11 Marsh

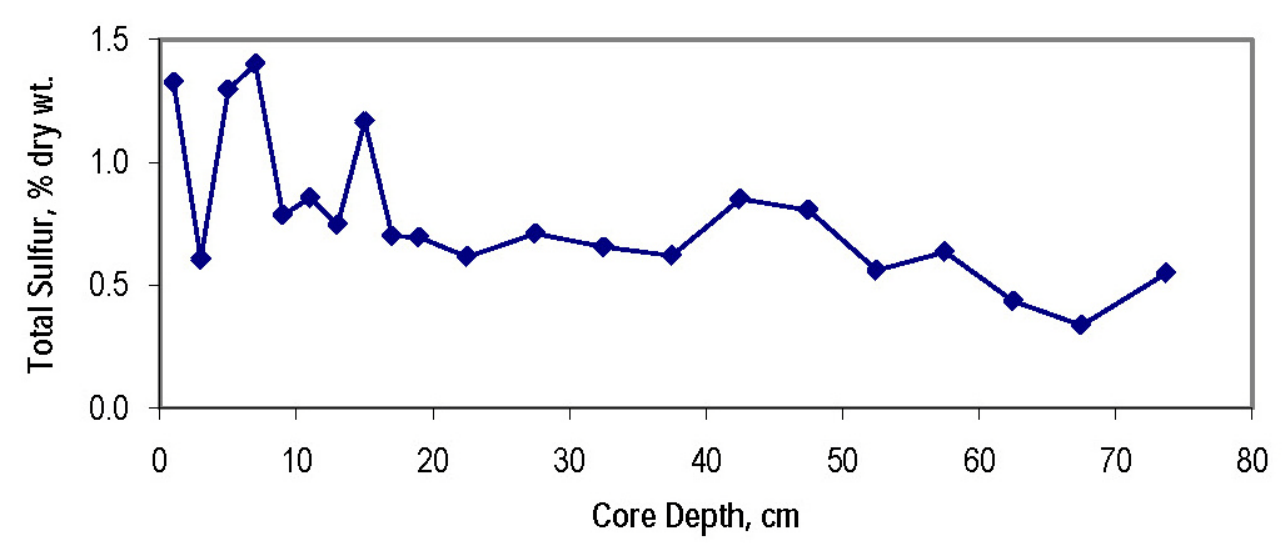

(C) Total Sulfur vs. Core Depth at L67 Rookery Island

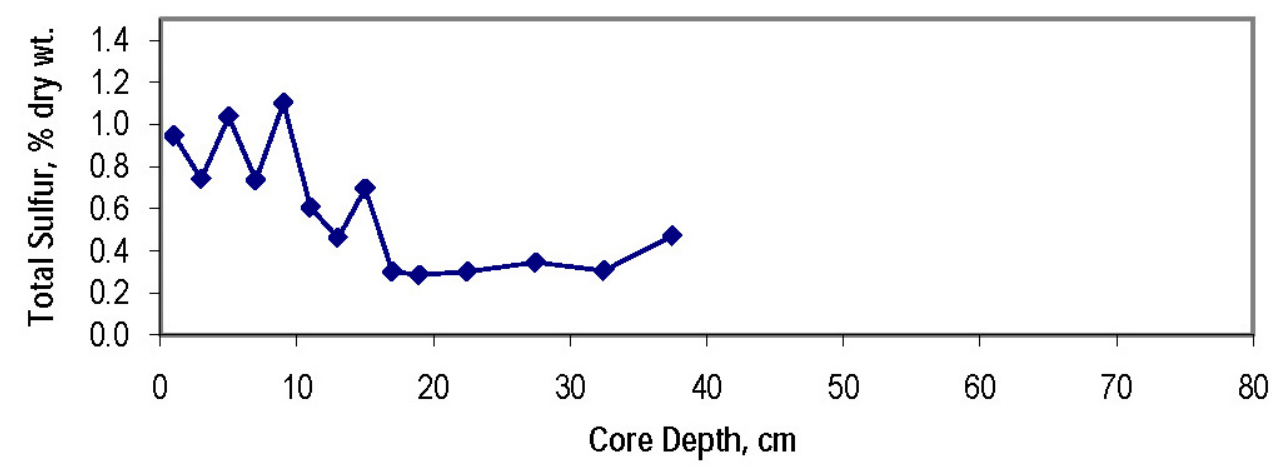

Figure 5. Graphs of total sulfur content (in percent dry weight) versus core depth (in centimeters) in soil cores from (A) the head of Tree Island 11 (TI-11), (B) the marsh of Tree Island 11, and (C) L67 Rookery Island. All samples were analyzed in duplicate; data points plotted are averages of duplicate results shown in table 3. 
(A) Total Phosphorus vs. Core Depth at Rescue Strand

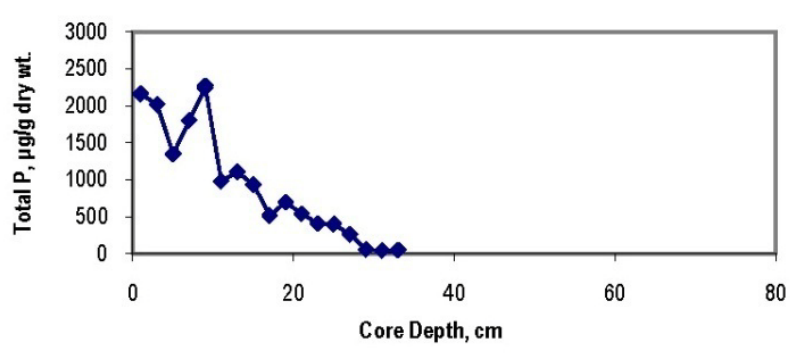

(C) Total Phosphorus vs. Core Depth at TI-11 Marsh

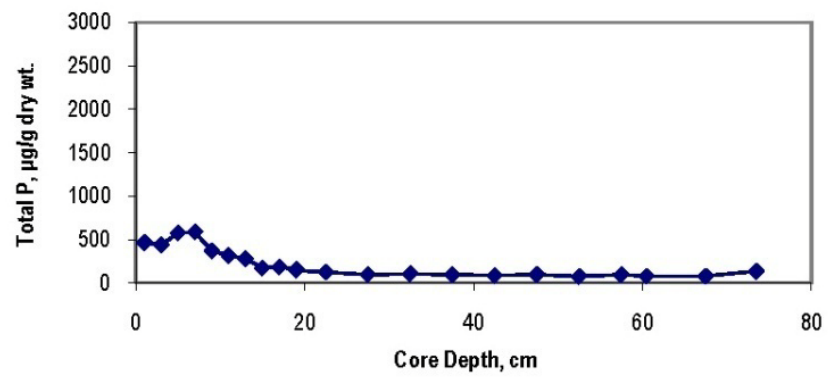

(B) Total Phosphorus vs Core Depth at TI-11 Head

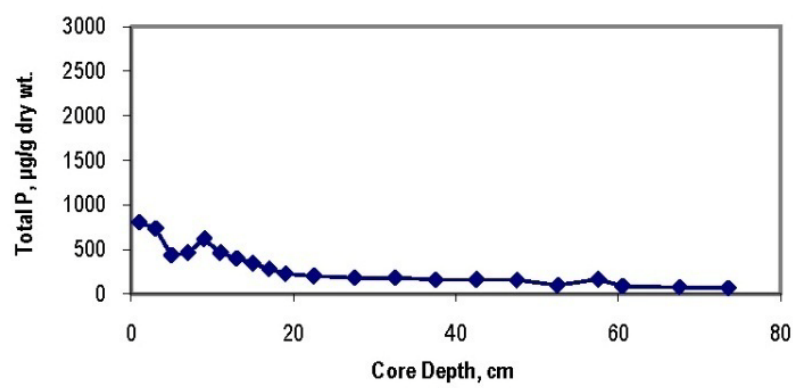

(D) Total Phosphorus vs. Core Depth at L67 Rookery Island

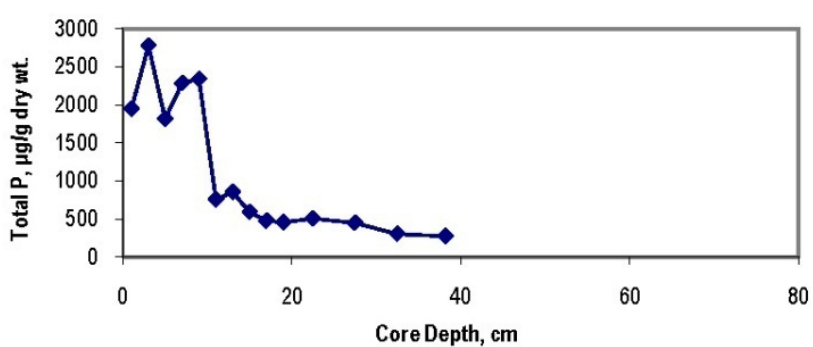

Figure 6. Graphs of total phosphorus content (in micrograms per gram dry weight) versus core depth (in centimeters) in soil cores from (A) Rescue Strand, (B) the head of Tree Island 11 (TI-11), (C) the marsh of Tree Island 11, and (D) L67 Rookery Island. Data plotted are from tables 4 and 5 for cores collected at Rescue Strand on June 22, 2005, in the head and marsh of Tree Island 11 on October 12, 2007, and on L67 Rookery Island on October 13, 2007. 
(A) Uric Acid vs. Total P at Rescue Strand

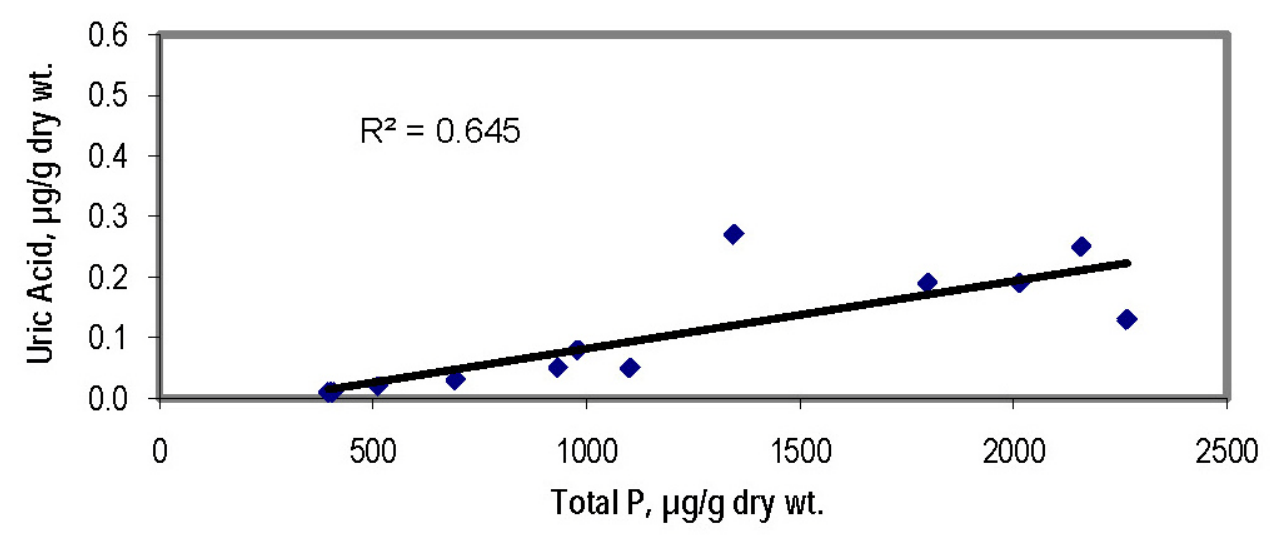

(B) Uric Acid vs. Total P at TI-11, Head

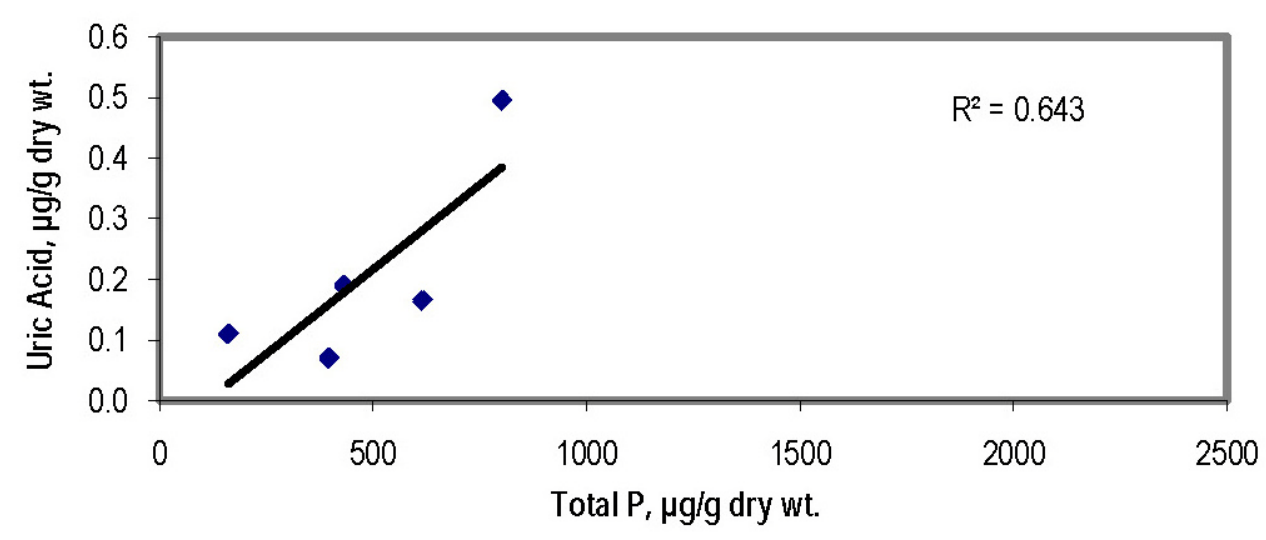

(C) Uric Acid vs. Total P at TI-11, Marsh

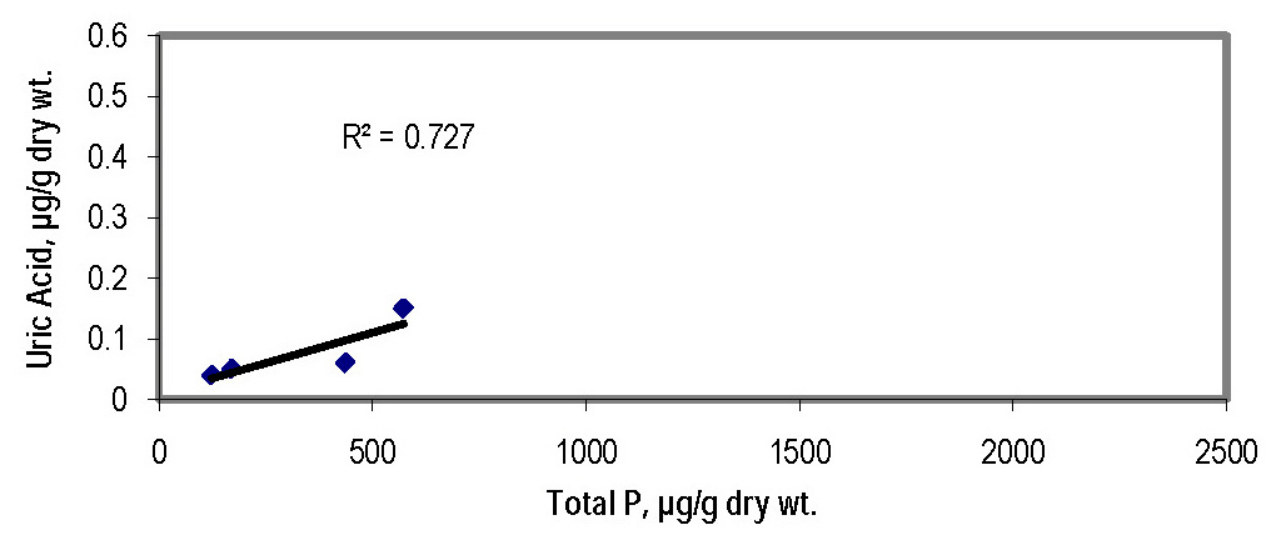

Figure 7. Graphs of uric acid content (in micrograms per gram dry weight) versus total phosphorus content (in micrograms per gram dry weight) in soil cores from (A) Rescue Strand, $(B)$ the head of Tree Island 11 (TI-11), and (C) the marsh of Tree Island 11. Data plotted are from tables 4, 5, 6, and 9. 
(A) Uric Acid vs. Total N, Rescue Strand

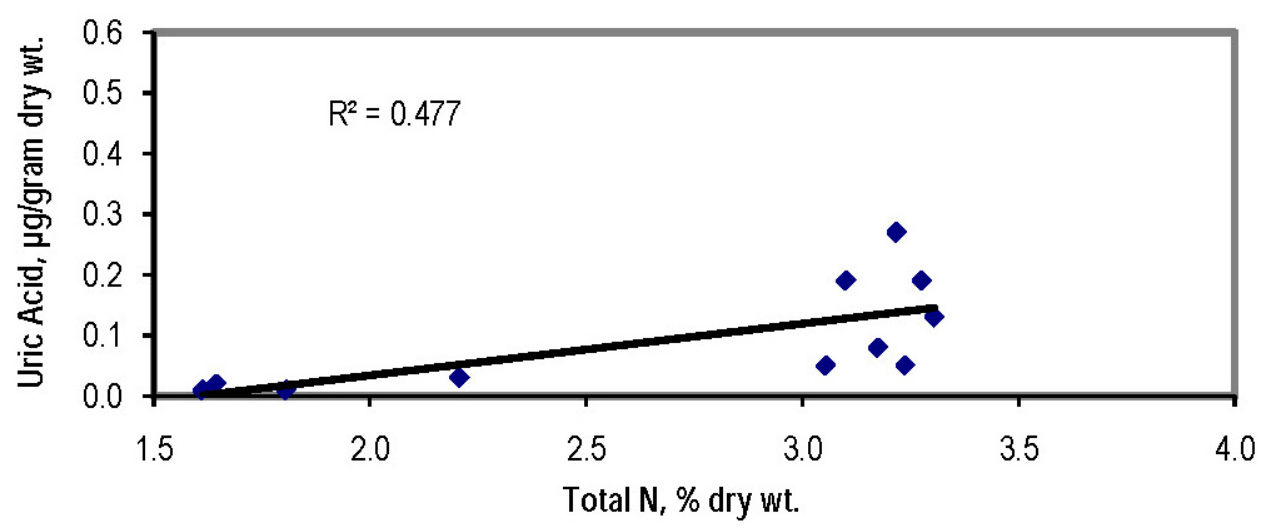

(B) Uric Acid vs. Total N, TI-11, Head

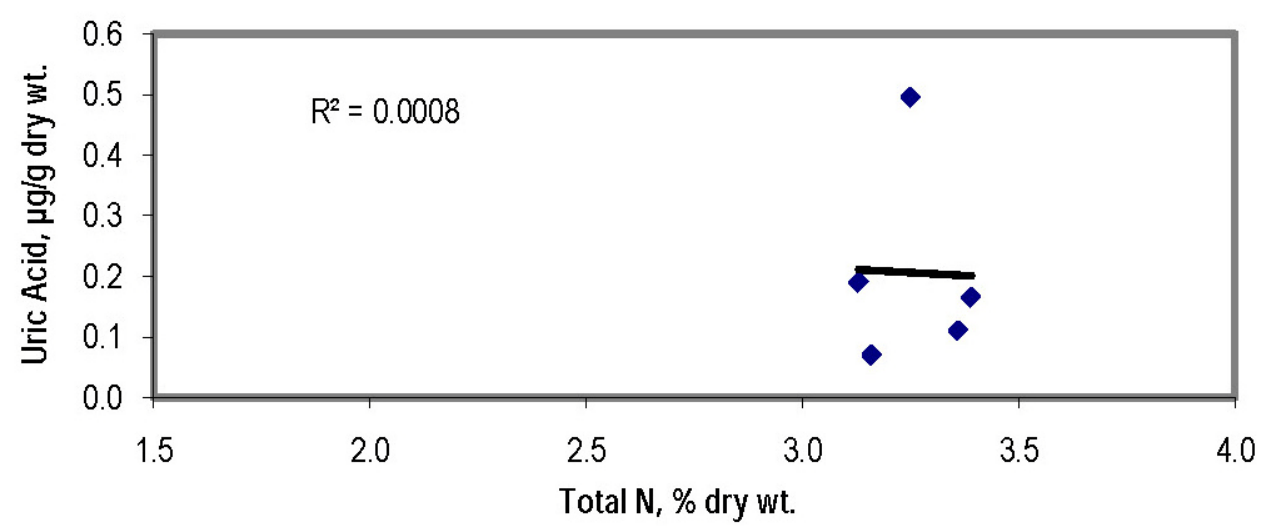

(C) Uric Acid vs. Total N, TI-11, Marsh

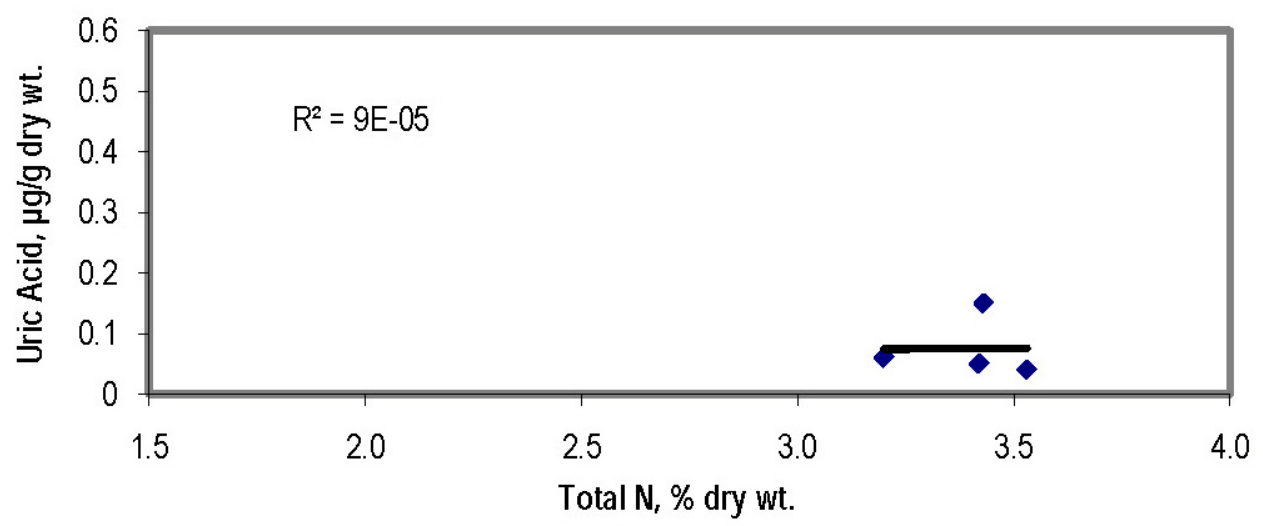

Figure 8. Graphs of uric acid content (in micrograms per gram dry weight) versus total nitrogen content (in percent dry weight) in soil cores from $(A)$ Rescue Strand, $(B)$ the head of Tree Island 11 (TI-11), and (C) the marsh of Tree Island 11. Data plotted are from tables $2,3,6$, and 9 . 
Table 1. Sampling data for soil samples collected in the Everglades, Florida, at Rescue Strand (June 2005), 5 Mile Head (March 2006), Tree Island 11 (October 2007), and L67 Rookery Island (October 2007).

[N/A, not applicable]

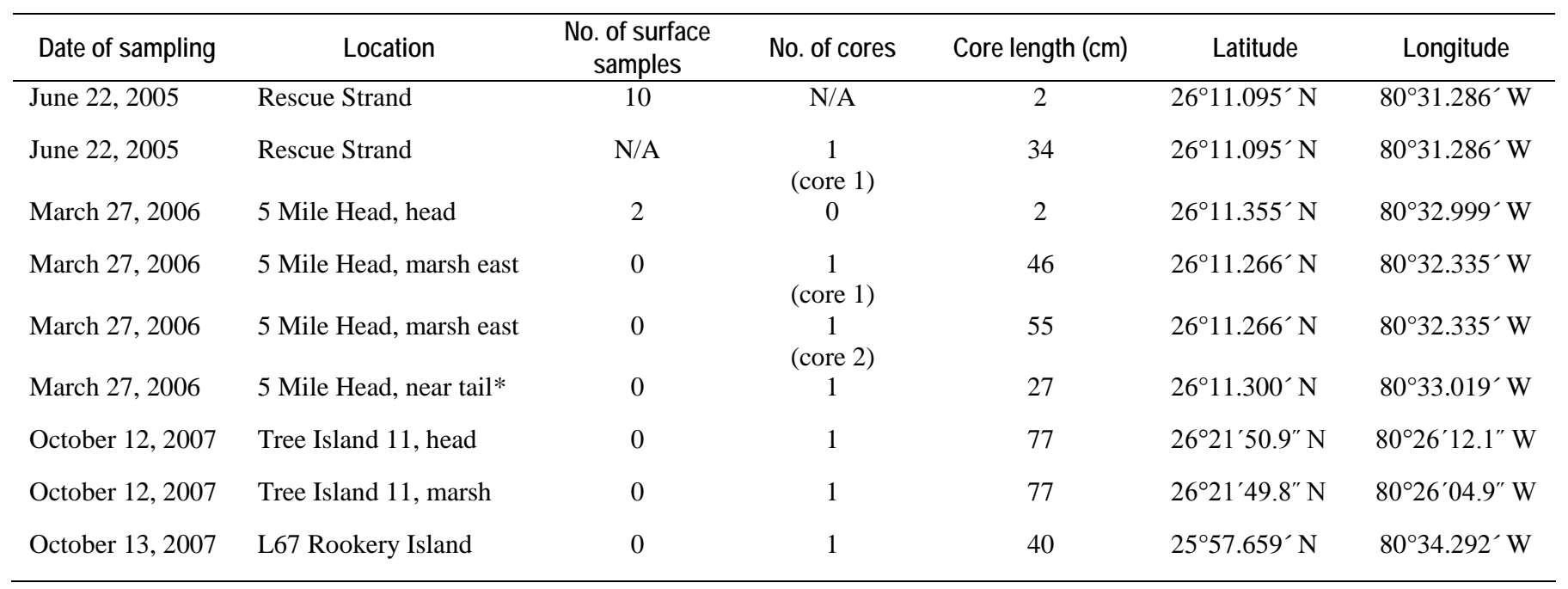

*The core from near the tail of 5 Mile Head was lost during transit from Florida to the U.S. Geological Survey facility in Reston, Va. 
Table 2. Total carbon $(\mathrm{C})$ and total nitrogen $(\mathrm{N})$ contents (in percent dry weight) for soil surface grab samples and core 1 segments collected at Rescue Strand on June 22, 2005.

[All samples were analyzed in duplicate. cm, centimeters]

\begin{tabular}{|c|c|c|c|}
\hline Sample & Depth (cm) & $\begin{array}{c}\text { Total C } \\
\text { (\% dry wt.) }\end{array}$ & $\begin{array}{c}\text { Total N } \\
\text { (\% dry wt.) }\end{array}$ \\
\hline \multirow{2}{*}{ Surface 1} & $0-2$ & 43.55 & 3.176 \\
\hline & & 42.03 & 3.645 \\
\hline \multirow[t]{2}{*}{ Surface 2} & $0-2$ & 47.09 & 3.305 \\
\hline & & 45.10 & 3.743 \\
\hline \multirow[t]{2}{*}{ Surface 3} & $0-2$ & 44.31 & 3.541 \\
\hline & & 43.58 & 3.365 \\
\hline \multirow[t]{2}{*}{ Surface 4} & $0-2$ & 46.36 & 3.480 \\
\hline & & 46.24 & 3.439 \\
\hline \multirow[t]{2}{*}{ Surface 5} & $0-2$ & 40.66 & 3.478 \\
\hline & & 42.20 & 3.620 \\
\hline \multirow[t]{2}{*}{ Surface 6} & $0-2$ & 45.96 & 2.759 \\
\hline & & 46.00 & 2.790 \\
\hline Core 1-0 & $0-2$ & nd* & nd* \\
\hline \multirow[t]{2}{*}{ Core 1-1 } & $2-4$ & 44.99 & 3.266 \\
\hline & & 44.94 & 3.286 \\
\hline \multirow[t]{2}{*}{ Core 1-2 } & $4-6$ & 47.91 & 3.126 \\
\hline & & 46.95 & 3.130 \\
\hline \multirow[t]{2}{*}{ Core 1-3 } & $6-8$ & 45.62 & 3.124 \\
\hline & & 45.80 & 3.077 \\
\hline \multirow[t]{2}{*}{ Core 1-4 } & $8-10$ & 41.84 & 3.296 \\
\hline & & 43.07 & 3.313 \\
\hline \multirow[t]{2}{*}{ Core 1-5 } & $10-12$ & 45.01 & 3.168 \\
\hline & & 44.58 & 3.181 \\
\hline \multirow[t]{2}{*}{ Core 1-6 } & $12-14$ & 44.82 & 3.253 \\
\hline & & 44.11 & 3.222 \\
\hline \multirow[t]{2}{*}{ Core 1-7 } & $14-16$ & 40.26 & 3.064 \\
\hline & & 40.14 & 3.044 \\
\hline \multirow{2}{*}{ Core 1-8 } & $16-18$ & 18.82 & 1.481 \\
\hline & & 22.71 & 1.806 \\
\hline \multirow[t]{2}{*}{ Core 1-9 } & $18-20$ & 31.03 & 2.287 \\
\hline & & 28.40 & 2.127 \\
\hline \multirow[t]{2}{*}{ Core $1-10$} & $20-22$ & 34.43 & 2.481 \\
\hline & & 31.94 & 2.307 \\
\hline \multirow[t]{2}{*}{ Core 1-11 } & $22-24$ & 25.71 & 1.813 \\
\hline & & 25.48 & 1.798 \\
\hline \multirow[t]{2}{*}{ Core 1-12 } & $24-26$ & 23.50 & 1.691 \\
\hline & & 20.85 & 1.533 \\
\hline \multirow[t]{2}{*}{ Core $1-13$} & $26-28$ & 24.78 & 1.988 \\
\hline & & 22.11 & 1.817 \\
\hline \multirow[t]{2}{*}{ Core 1-14 } & $28-30$ & 3.59 & 0.335 \\
\hline & & 2.61 & 0.257 \\
\hline \multirow[t]{2}{*}{ Core 1-15 } & $30-32$ & 1.82 & 0.179 \\
\hline & & 2.09 & 0.209 \\
\hline \multirow[t]{2}{*}{ Core 1-16 } & $32-34$ & 2.18 & 0.220 \\
\hline & & 1.92 & 0.201 \\
\hline
\end{tabular}

*No data (nd) are reported for core segment 1-0 due to insufficient dry sample. 
Table 3. Total carbon (TC), organic carbon (OC), total nitrogen (TN), and total sulfur (TS) contents in soil cores from the head and marsh of Tree Island 11 (TI-11) and from L67 Rookery Island.

[All samples were analyzed in duplicate. All data are in percent dry weight. The cores were collected on October 12 and 13, 2007. cm, centimeters; nd, no data]

\begin{tabular}{|c|c|c|c|c|c|c|c|c|c|c|c|c|}
\hline $\begin{array}{l}\text { Core } \\
\text { depth } \\
\text { (cm) }\end{array}$ & $\begin{array}{l}\text { TI-11 } \\
\text { head, } \\
\text { TC }\end{array}$ & $\begin{array}{c}\text { Tl-11 } \\
\text { head, } \\
\text { OC }\end{array}$ & $\begin{array}{c}\text { TI-11 } \\
\text { head, } \\
\text { TN }\end{array}$ & $\begin{array}{c}\text { Tl-11 } \\
\text { head, } \\
\text { TS }\end{array}$ & $\begin{array}{c}\text { TI-11 } \\
\text { marsh, } \\
\text { TC }\end{array}$ & $\begin{array}{c}\text { Tl-11 } \\
\text { marsh, } \\
\text { OC }\end{array}$ & $\begin{array}{c}\text { Tl-11 } \\
\text { marsh, } \\
\text { TN }\end{array}$ & $\begin{array}{c}\text { Tl-11 } \\
\text { marsh, } \\
\text { TS }\end{array}$ & $\begin{array}{l}\text { L67, } \\
\text { TC }\end{array}$ & $\begin{array}{l}\text { L67, } \\
\text { OC }\end{array}$ & $\begin{array}{l}\text { L67, } \\
\text { TN }\end{array}$ & $\begin{array}{l}\text { L67, } \\
\text { TS }\end{array}$ \\
\hline \multirow[t]{2}{*}{$0-2$} & 46.32 & 47.00 & 3.32 & 0.57 & 47.29 & 45.92 & 3.23 & 1.7 & 49.53 & 48.40 & 3.69 & 0.96 \\
\hline & 46.34 & 45.31 & 3.18 & 0.58 & 47.21 & 46.18 & 3.18 & 0.95 & 49.49 & 48.53 & 3.82 & 0.93 \\
\hline \multirow[t]{2}{*}{$2-4$} & 45.27 & 45.37 & 3.25 & 0.65 & 44.63 & 43.76 & 3.14 & 0.60 & 48.96 & 48.44 & 3.65 & 0.75 \\
\hline & 45.63 & 45.52 & 3.43 & 0.60 & 45.58 & 43.18 & 3.25 & 0.61 & 49.73 & 48.12 & 3.82 & 0.73 \\
\hline \multirow[t]{2}{*}{ 4-6 } & 46.45 & 46.68 & 3.25 & 0.52 & 45.99 & 45.67 & 3.42 & 0.93 & 49.88 & 49.73 & 3.93 & 0.99 \\
\hline & 45.76 & 46.02 & 3.00 & 0.49 & 45.92 & 45.72 & 3.44 & 1.66 & 50.25 & 49.97 & 3.92 & 1.08 \\
\hline \multirow[t]{2}{*}{$6-8$} & 45.18 & 46.52 & 3.33 & 0.43 & 46.32 & 45.56 & 3.39 & 1.02 & 49.12 & 48.61 & 3.05 & 0.76 \\
\hline & 45.39 & 46.06 & 3.39 & 0.43 & 45.86 & 45.59 & 3.46 & 1.78 & 49.97 & 45.14 & 3.17 & 0.71 \\
\hline \multirow[t]{2}{*}{$8-10$} & 46.85 & 46.10 & 3.57 & 0.99 & 46.40 & 45.86 & 3.24 & 0.77 & 49.40 & 48.92 & 3.51 & 0.72 \\
\hline & 45.39 & 45.52 & 3.21 & 0.39 & 46.67 & 45.56 & 3.24 & 0.80 & 49.11 & 48.62 & 3.46 & 1.48 \\
\hline \multirow[t]{2}{*}{$10-12$} & 47.05 & 46.19 & 3.32 & 0.71 & 48.83 & 48.26 & 3.32 & 0.92 & 47.40 & 47.23 & 3.38 & 0.58 \\
\hline & 46.83 & 46.68 & 3.28 & 0.38 & 48.80 & 48.30 & 3.21 & 0.79 & 47.11 & 47.82 & 3.32 & 0.63 \\
\hline \multirow[t]{2}{*}{$12-14$} & 47.90 & 46.79 & 3.19 & 1.00 & 50.29 & 49.49 & 3.36 & 0.79 & 46.93 & nd & 3.41 & 0.43 \\
\hline & 47.83 & 47.23 & 3.14 & 0.81 & 50.12 & 49.17 & 3.43 & 0.70 & 47.00 & 43.36 & 3.44 & 0.49 \\
\hline \multirow[t]{2}{*}{$14-16$} & 47.58 & 46.93 & 3.04 & 0.37 & 51.99 & 51.78 & 3.42 & 1.29 & 47.53 & nd & 3.09 & 1.03 \\
\hline & 47.89 & 46.77 & 3.13 & 0.38 & 52.41 & 51.56 & 3.42 & 1.04 & 47.56 & 47.35 & 3.11 & 0.36 \\
\hline \multirow[t]{2}{*}{$16-18$} & 48.81 & 48.81 & 2.92 & 0.34 & 52.30 & 52.26 & 3.46 & 0.70 & 48.53 & 49.30 & 3.02 & 0.31 \\
\hline & 47.94 & 48.18 & 2.90 & 0.76 & 52.27 & 52.25 & 3.61 & 0.70 & 48.79 & 48.54 & 2.98 & 0.29 \\
\hline \multirow[t]{2}{*}{$18-20$} & 47.94 & 49.25 & 2.76 & 0.71 & 52.74 & 52.93 & 3.75 & 0.72 & 49.11 & 48.89 & 2.84 & 0.29 \\
\hline & 47.13 & 48.64 & 2.75 & 0.30 & 52.51 & 52.03 & 3.75 & 0.67 & 48.96 & 48.91 & 2.86 & 0.28 \\
\hline \multirow[t]{2}{*}{$20-25$} & 48.76 & 48.45 & 2.65 & 0.31 & 53.05 & 52.84 & 3.88 & 0.60 & 48.37 & 47.87 & 2.65 & 0.31 \\
\hline & 48.33 & 48.36 & 2.72 & 0.33 & 53.13 & 52.61 & 3.97 & 0.63 & 48.28 & 48.06 & 2.65 & 0.29 \\
\hline \multirow[t]{2}{*}{$25-30$} & 49.47 & 48.96 & 2.90 & 0.35 & 52.22 & 51.58 & 3.59 & 0.75 & 47.86 & 48.15 & 2.76 & 0.33 \\
\hline & 50.22 & nd & 2.93 & 0.34 & 51.45 & 51.60 & 3.46 & 0.67 & 47.15 & 47.27 & 2.60 & 0.36 \\
\hline \multirow[t]{2}{*}{ 30-35 } & 50.47 & 50.12 & 3.05 & 0.74 & 52.57 & 52.09 & 3.54 & 0.69 & 50.24 & 50.12 & 3.00 & 0.30 \\
\hline & 50.21 & 50.19 & 3.01 & 0.32 & 52.25 & nd & 3.64 & 0.62 & 49.92 & 49.63 & 2.85 & 0.31 \\
\hline \multirow[t]{2}{*}{$35-40$} & 50.12 & 49.55 & 2.82 & 0.30 & 53.63 & 53.17 & 3.68 & 0.67 & 50.25 & 50.50 & 2.79 & 0.20 \\
\hline & 49.87 & 45.84 & 2.75 & 0.32 & 53.66 & 53.17 & 3.70 & 0.57 & 50.51 & 49.69 & 2.78 & 0.74 \\
\hline \multirow[t]{2}{*}{ 40-45 } & 51.01 & 50.37 & 3.04 & 0.32 & 52.57 & 53.12 & 3.35 & 0.58 & & & & \\
\hline & 50.41 & 50.60 & 3.04 & 0.32 & 52.60 & 51.65 & 3.30 & 1.12 & & & & \\
\hline \multirow[t]{2}{*}{$45-50$} & 52.33 & 52.37 & 2.98 & 0.36 & 53.36 & 53.03 & 3.96 & 1.05 & & & & \\
\hline & 52.21 & 51.72 & 3.04 & 0.37 & 53.23 & 52.85 & 3.88 & 0.56 & & & & \\
\hline \multirow[t]{2}{*}{ 50-55 } & 52.04 & 52.11 & 2.78 & 0.41 & 52.98 & 52.73 & 3.58 & 0.53 & & & & \\
\hline & 51.98 & 51.41 & 2.70 & 0.40 & 52.55 & 54.54 & 3.47 & 0.59 & & & & \\
\hline \multirow[t]{2}{*}{$55-60$} & 53.13 & 52.13 & 3.36 & 0.42 & 53.62 & 53.26 & 3.14 & 0.81 & & & & \\
\hline & 53.06 & 52.97 & 3.35 & 0.42 & 52.86 & 53.08 & 3.05 & 0.46 & & & & \\
\hline \multirow[t]{2}{*}{$60-65$} & 53.14 & 52.70 & 3.32 & 0.90 & 53.14 & 53.30 & 2.83 & 0.42 & & & & \\
\hline & 53.12 & 53.08 & 3.34 & 0.86 & 53.30 & 52.48 & 2.87 & 0.45 & & & & \\
\hline \multirow[t]{2}{*}{$65-70$} & 52.96 & 52.90 & 2.91 & 0.82 & 53.97 & 53.99 & 2.90 & 0.32 & & & & \\
\hline & 53.09 & 51.89 & 2.90 & 0.37 & 53.52 & 53.77 & 2.92 & 0.35 & & & & \\
\hline \multirow[t]{2}{*}{$70-77$} & 52.91 & 53.53 & 2.60 & 0.37 & 54.17 & 54.53 & 3.14 & 0.73 & & & & \\
\hline & 53.52 & 52.74 & 2.69 & 0.71 & 54.12 & 53.78 & 3.11 & 0.37 & & & & \\
\hline
\end{tabular}


Table 4. Total phosphorus $(P)$ content (in micrograms per gram dry weight) for soil surface grab samples and core 1 segments collected at Rescue Strand on June 22, 2005.

\begin{tabular}{lcr}
\hline Sample & $\begin{array}{c}\text { Depth } \\
(\mathbf{c m})\end{array}$ & $\begin{array}{r}\text { Total P } \\
(\boldsymbol{\mu} \text { g/g } \\
\text { dry wt.) }\end{array}$ \\
\hline Surface 1 & $0-2$ & 2,258 \\
Surface 3 & $0-2$ & 4,000 \\
Surface 4 & $0-2$ & 2,020 \\
Surface 5 & $0-2$ & 11,081 \\
Surface 6 & $0-2$ & 2,245 \\
& & \\
Core 1-0 & $0-2$ & 2,159 \\
Core 1-1 & $2-4$ & 2,014 \\
Core 1-2 & $4-6$ & 1,345 \\
Core 1-3 & $6-8$ & 1,799 \\
Core 1-4 & $8-10$ & 2,234 \\
Core 1-5 & $10-12$ & 980 \\
Core 1-6 & $12-14$ & 1,102 \\
Core 1-7 & $14-16$ & 933 \\
Core 1-8 & $16-18$ & 513 \\
Core 1-9 & $18-20$ & 693 \\
Core 1-10 & $20-22$ & 540 \\
Core 1-11 & $22-24$ & 406 \\
Core 1-12 & $24-26$ & 397 \\
Core 1-13 & $26-28$ & 259 \\
Core 1-14 & $28-30$ & 56 \\
Core 1-15 & $30-32$ & 39 \\
Core 1-16 & $32-34$ & 46 \\
\hline
\end{tabular}


Table 5. Total phosphorus content (in micrograms per gram dry weight) in soil cores from the head and marsh of Tree Island 11 (TI-11) and from L67 Rookery Island.

[The cores were collected on October 12 and 13, 2007. The core from L67 Rookery Island was 40 centimeters $(\mathrm{cm})$ long. N/A, not applicable]

\begin{tabular}{lccc}
\hline $\begin{array}{c}\text { Core depth } \\
(\mathbf{c m})\end{array}$ & $\begin{array}{c}\text { TI-11 head } \\
(\mu \mathrm{g} / \mathrm{g})\end{array}$ & $\begin{array}{c}\text { Tl-11 marsh } \\
(\boldsymbol{\mu} \mathrm{g} / \mathrm{g})\end{array}$ & $\begin{array}{c}\text { L67 Rookery Island } \\
(\boldsymbol{\mu} \mathrm{g} / \mathrm{g})\end{array}$ \\
\hline $0-2$ & 803 & 463 & 1,944 \\
$2-4$ & 733 & 436 & 2,776 \\
$4-6$ & 432 & 573 & 1,814 \\
$6-8$ & 460 & 585 & 2,285 \\
$8-10$ & 617 & 367 & 2,339 \\
$10-12$ & 460 & 313 & 752 \\
$12-14$ & 397 & 276 & 852 \\
$14-16$ & 340 & 169 & 588 \\
$16-18$ & 280 & 181 & 573 \\
$18-20$ & 222 & 153 & 455 \\
$20-25$ & 199 & 143 & 503 \\
$25-30$ & 179 & 123 & 446 \\
$30-35$ & 179 & 95 & 300 \\
$35-40$ & 158 & 102 & 273 \\
$40-45$ & 160 & 92 & N/A \\
$45-50$ & 154 & 95 & N/A \\
$50-55$ & 95 & 72 & N/A \\
$55-60$ & 162 & 92 & N/A \\
$60-65$ & 84 & 77 & N/A \\
$65-70$ & 72 & 76 & N/A \\
$70-77$ & 63 & 133 & N/A \\
\hline
\end{tabular}


Table 6. Uric acid content (in micrograms per gram dry weight) for soil surface grab samples, core 1 segments, and bird guano collected at Rescue Strand on June 22, 2005.

[cm, centimeters; $<\mathrm{dl}$, below the detection limit]

\begin{tabular}{lcc}
\hline \multicolumn{1}{c}{ Sample } & $\begin{array}{c}\text { Depth } \\
(\mathbf{c m})\end{array}$ & $\begin{array}{c}\text { Uric acid } \\
(\mu \mathrm{g} / \mathrm{g} \text { sample })\end{array}$ \\
\hline Bird guano (wet) & $0-2($ surface) & 316 \\
Surface 1 & $0-2$ & \\
Surface 2 & $0-2$ & 7.9 \\
Surface 3 & $0-2$ & 3.2 \\
Surface 4 & $0-2$ & 1.2 \\
Surface 5 & $0-2$ & 0.5 \\
Surface 6 & $0-2$ & 5.0 \\
Surface 9 & $0-2$ & 0.5 \\
Surface 10 & $0-2$ & 0.7 \\
& & 0.8 \\
Core 1-0 & $0-2$ & \\
Core 1-1 & $2-4$ & 0.25 \\
Core 1-2 & $4-6$ & 0.19 \\
Core 1-3 & $6-8$ & 0.27 \\
Core 1-4 & $8-10$ & 0.19 \\
Core 1-5 & $10-12$ & 0.13 \\
Core 1-6 & $12-14$ & 0.08 \\
Core 1-7 & $14-16$ & 0.05 \\
Core 1-8 & $16-18$ & 0.05 \\
Core 1-9 & $18-20$ & 0.02 \\
Core 1-10 & $20-22$ & 0.03 \\
Core 1-11 & $22-24$ & $<\mathrm{dl}$ \\
Core 1-12 & $24-26$ & 0.01 \\
Core 1-13 & $26-28$ & 0.01 \\
Core 1-14 & $28-30$ & $<\mathrm{dl}$ \\
Core 1-15 & $30-32$ & $<\mathrm{dl}$ \\
Core 1-16 & $32-34$ & $<\mathrm{dl}$ \\
\hline
\end{tabular}


Table 7. Uric acid content (in micrograms per gram dry weight) in bird droppings collected from nests (samples BB-1a through BB-11a and BB-12 through BB-15) and chicks (samples BB-1b through BB-11b).

\begin{tabular}{|c|c|c|c|}
\hline Sample ID & $\begin{array}{l}\text { Sample } \\
\text { source }\end{array}$ & Bird ID* & $\begin{array}{c}\text { Uric acid } \\
\text { ( } \mu \text { g/g dry wt.) }\end{array}$ \\
\hline BB-1a & Nest & WHIB & $\begin{array}{l}12,932 \\
13,680\end{array}$ \\
\hline BB-1b & Chick & WHIB & $\begin{array}{r}9,789 \\
\text { nd** }\end{array}$ \\
\hline BB-2a & Nest & GLIB & $\begin{array}{l}21,989 \\
25,120\end{array}$ \\
\hline BB-2b & Chick & GLIB & $\begin{array}{l}6,890 \\
6,930\end{array}$ \\
\hline BB-3a & Nest & WHIB & $\begin{array}{l}25,880 \\
28,791\end{array}$ \\
\hline BB-3b & Chick & WHIB & $\begin{array}{r}1,221 \\
\text { nd** }\end{array}$ \\
\hline BB-4a & Nest & WHIB & $\begin{array}{l}18,718 \\
20,219\end{array}$ \\
\hline BB-4b & Chick & WHIB & $\begin{array}{r}1,113 \\
\text { nd** }\end{array}$ \\
\hline BB-5a & Nest & WHIB & $\begin{array}{l}20,446 \\
20,986\end{array}$ \\
\hline BB-5b & Chick & WHIB & $\begin{array}{r}1,046 \\
\text { nd** }\end{array}$ \\
\hline BB-6a & Nest & WHIB & $\begin{array}{l}40,393 \\
44,635\end{array}$ \\
\hline BB-6b & Chick & WHIB & $\begin{array}{l}23,253 \\
23,754\end{array}$ \\
\hline BB-7a & Nest & WHIB & $\begin{array}{l}26,791 \\
27,817\end{array}$ \\
\hline BB-7b & Chick & WHIB & $\begin{array}{l}21,387 \\
22,157\end{array}$ \\
\hline BB-8a & Nest & GREG & $\begin{array}{l}49,198 \\
73,108\end{array}$ \\
\hline BB-8b & Chick & GREG & $\begin{array}{l}15,296 \\
15,432\end{array}$ \\
\hline BB-9a & Nest & GREG & $\begin{array}{l}57,889 \\
81,257\end{array}$ \\
\hline BB-9b & Chick & GREG & $\begin{array}{r}62,547 \\
\text { nd }^{* *}\end{array}$ \\
\hline BB-10a & Nest & GREG & $\begin{array}{l}14,586 \\
15,159\end{array}$ \\
\hline BB-10b & Chick & GREG & $\begin{array}{l}14,586 \\
15,159\end{array}$ \\
\hline BB-11a & Nest & GREG & $\begin{array}{l}36,868 \\
41,067\end{array}$ \\
\hline BB-11b & Chick & GREG & $\begin{array}{r}1,742 \\
\text { nd** }\end{array}$ \\
\hline BB-12 & Nest & TRHE & $\begin{array}{l}43,310 \\
64,176\end{array}$ \\
\hline BB-13 & Nest & TRHE & $\begin{array}{l}47,540 \\
53,311\end{array}$ \\
\hline BB-14 & Nest & GREG & $\begin{array}{l}34,064 \\
50,117\end{array}$ \\
\hline BB-15 & Nest & GREG & $\begin{array}{l}12,287 \\
12,493 \\
\end{array}$ \\
\hline
\end{tabular}

*WHIB, White Ibis; GLIB, Glossy Ibis; GREG, Great Egret; TRHE, Tricolored Heron.

**nd, no data (duplicate was not run on this chick sample). 
Table 8. Uric acid content (in micrograms per gram dry weight) in core segments and surface grab samples from Five Mile Head.

[Terms: -- (dashes), no sample to analyze; <dl, below the detection limit; nd, no data]

\begin{tabular}{|c|c|c|c|c|c|}
\hline $\begin{array}{l}\text { Depth } \\
\text { (cm) }\end{array}$ & $\begin{array}{l}\text { Leaves with } \\
\text { bird } \\
\text { droppings } \\
(\mu \mathrm{g} / \mathrm{g})\end{array}$ & $\begin{array}{r}\text { Surface-1, } \\
\text { head }(\mu \mathrm{g} / \mathrm{g})\end{array}$ & $\begin{array}{c}\text { Surface-2, } \\
\text { head }(\mu \mathrm{g} / \mathrm{g})\end{array}$ & $\begin{array}{c}\text { Core 1, } \\
\text { marsh } \\
\text { east } \\
(\mu \mathrm{g} / \mathrm{g})\end{array}$ & $\begin{array}{c}\text { Core 2, } \\
\text { marsh } \\
\text { east } \\
(\mu \mathrm{g} / \mathrm{g})\end{array}$ \\
\hline $0-2$ & 18,290 & -- & -- & -- & -- \\
\hline $0-2$ & -- & 6.46 & $<\mathrm{dl}$ & -- & -- \\
\hline $0-2$ & -- & 1.62 & $<\mathrm{dl}$ & -- & -- \\
\hline $0-2$ & -- & 0.30 & 0.15 & -- & -- \\
\hline $0-2$ & -- & 0.36 & $<\mathrm{dl}$ & -- & -- \\
\hline $0-2$ & -- & 3.09 & -- & -- & -- \\
\hline $0-2$ & -- & 0.09 & -- & -- & -- \\
\hline $0-2$ & -- & $<\mathrm{dl}$ & -- & -- & -- \\
\hline $0-2$ & -- & 1.03 & -- & -- & -- \\
\hline $0-2$ & -- & 1.34 & -- & -- & -- \\
\hline $0-2$ & -- & -- & -- & $\begin{array}{l}--* \\
--*\end{array}$ & $\begin{array}{l}1.12 \\
1.15\end{array}$ \\
\hline $2-4$ & -- & -- & -- & $\begin{array}{l}0.00 \\
0.30\end{array}$ & $\begin{array}{l}0.90 \\
1.11\end{array}$ \\
\hline $20-22$ & -- & -- & -- & $\begin{array}{l}<\mathrm{dl} \\
<\mathrm{dl}\end{array}$ & $\begin{array}{l}\text { nd } \\
\text { nd }\end{array}$ \\
\hline $24-26$ & -- & -- & -- & $\begin{array}{l}\text { nd } \\
\text { nd }\end{array}$ & $\begin{array}{l}0.07 \\
0.39\end{array}$ \\
\hline $38-40$ & -- & -- & -- & $\begin{array}{l}<\mathrm{dl} \\
<\mathrm{dl}\end{array}$ & $\begin{array}{l}\text { nd } \\
\text { nd }\end{array}$ \\
\hline $44-46$ & $\begin{array}{l}-- \\
--\end{array}$ & $\begin{array}{l}-- \\
--\end{array}$ & $\begin{array}{l}-- \\
--\end{array}$ & $\begin{array}{l}-- \\
--\end{array}$ & $\begin{array}{l}<\mathrm{dl} \\
<\mathrm{dl}\end{array}$ \\
\hline
\end{tabular}

*The segment of core 1 from 0-2 cm was not analyzed due to lack of enough solid material. 
Table 9. Uric acid content (in micrograms per gram dry weight) in soil cores from the head and marsh of Tree Island 11 (TI-11) and L67 Rookery Island.

[Terms: cm, centimeters; <ql, uric acid was detectable by mass spectrometry single-ion recording (MS SIR) but was present below the level of accurate quantification $(<0.05 \mu \mathrm{g} / \mathrm{mL}$ in the extract); $<\mathrm{dl}$, uric acid was below detection limit; N/A, not applicable because the core from L67 Rookery Island was $40 \mathrm{~cm}$ long]

\begin{tabular}{|c|c|c|c|}
\hline $\begin{array}{l}\text { Core depth } \\
\text { (cm) }\end{array}$ & $\begin{array}{l}\text { TI-11, head } \\
(\mu \mathrm{g} / \mathrm{g})\end{array}$ & $\begin{array}{l}\text { TI-11, marsh } \\
(\mu \mathrm{g} / \mathrm{g})\end{array}$ & $\begin{array}{l}\text { L67 Rookery Island } \\
(\mu \mathrm{g} / \mathrm{g})\end{array}$ \\
\hline \multirow[t]{2}{*}{$0-2$} & 0.61 & $<\mathrm{ql}$ & $<\mathrm{dl}$ \\
\hline & 0.38 & $<\mathrm{ql}$ & $<\mathrm{dl}$ \\
\hline \multirow[t]{2}{*}{$2-4$} & 0.17 & 0.05 & $<\mathrm{dl}$ \\
\hline & 0.21 & 0.07 & $<\mathrm{ql}$ \\
\hline \multirow[t]{2}{*}{$4-6$} & 0.15 & 0.17 & $<\mathrm{dl}$ \\
\hline & 0.18 & 0.13 & $<\mathrm{dl}$ \\
\hline \multirow[t]{2}{*}{$6-8$} & 0.07 & $<\mathrm{dl}$ & $<\mathrm{dl}$ \\
\hline & 0.07 & $<\mathrm{ql}$ & $<\mathrm{dl}$ \\
\hline \multirow[t]{2}{*}{$8-10$} & $<\mathrm{ql}$ & $<\mathrm{dl}$ & $<\mathrm{dl}$ \\
\hline & $<\mathrm{ql}$ & $<\mathrm{dl}$ & $<\mathrm{dl}$ \\
\hline \multirow[t]{2}{*}{$10-12$} & $<\mathrm{ql}$ & $<\mathrm{ql}$ & $<\mathrm{dl}$ \\
\hline & $<\mathrm{ql}$ & $<\mathrm{ql}$ & $<\mathrm{dl}$ \\
\hline \multirow[t]{2}{*}{$12-14$} & $<\mathrm{ql}$ & $<\mathrm{dl}$ & $<\mathrm{dl}$ \\
\hline & $<\mathrm{ql}$ & $<\mathrm{dl}$ & $<\mathrm{ql}$ \\
\hline \multirow[t]{2}{*}{$14-16$} & $<\mathrm{ql}$ & $<\mathrm{dl}$ & $<\mathrm{dl}$ \\
\hline & $<\mathrm{ql}$ & 0.10 & $<\mathrm{dl}$ \\
\hline \multirow[t]{2}{*}{$16-18$} & $<\mathrm{ql}$ & $<\mathrm{ql}$ & $<\mathrm{dl}$ \\
\hline & $<\mathrm{ql}$ & $<\mathrm{ql}$ & $<\mathrm{dl}$ \\
\hline \multirow[t]{2}{*}{$18-20$} & 0.15 & $<\mathrm{dl}$ & $<\mathrm{dl}$ \\
\hline & 0.07 & $<\mathrm{dl}$ & $<\mathrm{dl}$ \\
\hline \multirow[t]{2}{*}{$20-25$} & $<\mathrm{dl}$ & $<\mathrm{dl}$ & $<\mathrm{dl}$ \\
\hline & $<\mathrm{dl}$ & $<\mathrm{dl}$ & $<\mathrm{dl}$ \\
\hline \multirow[t]{2}{*}{$25-30$} & $<\mathrm{ql}$ & $<\mathrm{dl}$ & $<\mathrm{dl}$ \\
\hline & $<\mathrm{ql}$ & 0.08 & $<\mathrm{dl}$ \\
\hline \multirow[t]{2}{*}{$30-35$} & $<\mathrm{dl}$ & $<\mathrm{dl}$ & $<\mathrm{dl}$ \\
\hline & $<\mathrm{dl}$ & $<\mathrm{dl}$ & $<\mathrm{dl}$ \\
\hline \multirow[t]{2}{*}{$35-40$} & $<\mathrm{dl}$ & $<\mathrm{dl}$ & $<\mathrm{dl}$ \\
\hline & $<\mathrm{dl}$ & $<\mathrm{dl}$ & $<\mathrm{dl}$ \\
\hline $45-50$ & $<1$ & $<\mathrm{ql}$ & N/A \\
\hline $55-60$ & $<\mathrm{ql}$ & $<\mathrm{ql}$ & N/A \\
\hline $65-70$ & $<\mathrm{dl}$ & $<\mathrm{dl}$ & N/A \\
\hline \multirow[t]{2}{*}{$70-77$} & $<\mathrm{dl}$ & $<\mathrm{dl}$ & N/A \\
\hline & $<\mathrm{dl}$ & $<\mathrm{dl}$ & \\
\hline
\end{tabular}

